\title{
Hydrogen Emanations in Intracratonic Areas: New Guide Lines for Early Exploration Basin Screening
}

\author{
Isabelle Moretti ${ }^{1, *(\mathbb{D}}$, Emyrose Brouilly ${ }^{1,2}{ }^{-}$, Keanu Loiseau ${ }^{1}$, Alain Prinzhofer ${ }^{3}$ and Eric Deville ${ }^{4}$ \\ 1 UPPA, LFCR, Rue de L'université, 64000 Pau, France; emyrose.brouilly@gmx.fr (E.B.); \\ kloiseau@univ-pau.fr (K.L.) \\ 2 Department of Geosciences, University of Rennes, 35000 Rennes, France \\ 3 Geo4U, Rio de Janeiro 22250-040, Brazil; prinzhofer2@gmail.com \\ 4 Ifpschool, 92852 Rueil Malmaison, France; eric.deville@ifpen.fr \\ * Correspondence: isabelle.moretti@univ-pau.fr
}

\section{check for} updates

Citation: Moretti, I.; Brouilly, E.; Loiseau, K.; Prinzhofer, A.; Deville, E. Hydrogen Emanations in Intracratonic Areas: New Guide Lines for Early Exploration Basin Screening. Geosciences 2021, 11, 145 https://doi.org/10.3390/ geosciences 11030145

\section{Academic Editors:}

Jesus Martinez-Frias and Andrea Brogi

Received: 2 February 2021

Accepted: 10 March 2021

Published: 22 March 2021

Publisher's Note: MDPI stays neutral with regard to jurisdictional claims in published maps and institutional affiliations.

Copyright: (c) 2021 by the authors. Licensee MDPI, Basel, Switzerland. This article is an open access article distributed under the terms and conditions of the Creative Commons Attribution (CC BY) license (https:// creativecommons.org/licenses/by/ $4.0 /)$.

\begin{abstract}
Offshore the emissions of dihydrogen are highlighted by the smokers along the oceanic ridges. Onshore in situ measurements in ophiolitic contexts and in old cratons have also proven the existence of numerous $\mathrm{H}_{2}$ emissive areas. When $\mathrm{H}_{2}$ emanations affect the soils, small depressions and vegetation gaps are observed. These depressions, called fairy circles, have similarities with the pockmark and vent structures recognized for long time in the sea floor when natural gas escapes but also differences. In this paper we present a statistic approach of the density, size, and shape of the fairy circles in various basins. New data from Brazil and Australia are compared to the existing database already gathered in Russia, USA, and again Brazil. The comparison suggests that Australia could be one of the most promising areas for $\mathrm{H}_{2}$ exploration, de facto a couple of wells already found $\mathrm{H}_{2}$, whereas they were drilled to look for hydrocarbons. The sum of areas from where $\mathrm{H}_{2}$ is seeping overpasses $45 \mathrm{~km}^{2}$ in Kangaroo Island as in the Yorke Peninsula. The size of the emitting structures, expressed in average diameter, varies from few meters to kilometers and the footprint expressed in $\%$ of the ground within the structures varies from 1 to $17 \%$. However, globally the sets of fairy circles in the various basins are rather similar and one may consider that their characteristics are homogeneous and may help to characterize these $\mathrm{H}_{2}$ emitting zones. Two kinds of size repartitions are observed, one with two maxima ( $25 \mathrm{~m}$ and between $220 \mathrm{~m} \pm 25 \%$ ) one with a simple Gaussian shape with a single maximum around $175 \mathrm{~m} \pm 20 \%$. Various geomorphological characteristics allow us to differentiate depressions of the ground due to gas emissions from karstic dolines. The more relevant ones are their slope and the ratio diameter vs. depth. At the opposite of the pockmark structures observed on the seafloor for which exclusion zones have been described, the $\mathrm{H}_{2}$ emitting structures may intersect and they often growth by coalescence. These $\mathrm{H}_{2}$ emitting structures are always observed, up to now, above Archean or Neoproterozoic cratons; it suggests that anoxia at the time the sedimentation and iron content play a key role in the $\mathrm{H}_{2}$ sourcing.
\end{abstract}

Keywords: natural hydrogen; Brazil; Australia; Russia; gas escape

\section{Introduction}

\subsection{Native Hydrogen: An Overview}

Hydrogen has been present in the industry as a raw material for long time and, except for rocket takeoff, its energetic capacity was almost never used, at least for the second part of the 20th century. The landscape is changing since green fuels are looked for to decrease the $\mathrm{CO}_{2}$ impact of the mobility and to improve the air quality of the cities. The use of $\mathrm{H}_{2}$ as fuel is growing and the demand of green hydrogen, not manufactured from hydrocarbons, is following the same trend. In that frame, the production of native $\mathrm{H}_{2}$ appears as a promising alternative [1-3] and exploration is starting in various countries after the fortuitous discoveries of accumulations in different places and the first years of production in Mali [4]. It should be noted that some authors already alerted the scientific 
community some time ago on that resource [5] without receiving any attention from the extractive industry but times are changing.

Even if some questions remain open, the geological contexts that allow $\mathrm{H}_{2}$ generation in subsurface started to be known and natural $\mathrm{H}_{2}$ has already been noticed in three geological tectonic settings:

(C_1) extension zones (Mid Oceanic Ridge, Iceland, and African Rift);

(C_2) compression zones involving ophiolitic nappes (Oman, Philippines, New Caledonia); and

(C_3) stable intracratonic basins above Archean to Proterozoic basement.

The present paper focuses on this third geological context.

$\mathrm{H}_{2}$ has been also measured within or near large faults, in many stress regimes, normal fault, thrust fault as well as shear zones [6]; a mechanism of $\mathrm{H}_{2}$ generation by mechanoradical reactions on the wet surfaces of the faults is proposed (Klein et al., 2020). These punctual emissions are related to the fault activity and these very specific local sources will not be discussed here.

Natural gases, such as the methane, may have different origins in the subsurface: the maturation of a source rock and/or the secondary cracking of heavier hydrocarbons, the microbial activity and finally the fluid-rock interaction. Depending of its origin the methane is called thermogenic, biogenic, or abiotic. Isotopic data allow us to define this origin [7] although ambiguities may remain. Similarly, origins of $\mathrm{H}_{2}$ present in subsurface may be varied [8,9], among others, we can divide them in three groups and, since the understanding of all these phenomena is still partial and fragmented, the most likely origin of $\mathrm{H}_{2}$ varies according to the authors.

(O_1) $\mathrm{H}_{2}$ may come from water/rock interaction in the crust. Within this case, the origin of $\mathrm{H}_{2}$ is the water. The $\mathrm{H}_{2} \mathrm{O}$ reduction and the release of $\mathrm{H}_{2}$ could be caused by the oxidation of mineral rich rocks such as olivine, or by the radiolysis induced by the natural radioactivity of rocks such as granite.

(O_2) $\mathrm{H}_{2}$ may be generated by bacterial/algae activity near the surface; and finally

(O_3) $\mathrm{H}_{2}$ may come from a deep source and corresponds to the primordial $\mathrm{H}_{2}$ of the solar system.

As for methane, we do not anticipate that the $\mathrm{H}_{2}$ emanations observed in the Earth all have the same origins. The relative proportions as well as the absolute quantities of $\mathrm{H}_{2}$ that could be released by these various processes are still mainly unknown. In case of $\mathrm{H}_{2}$ coming from $\mathrm{H}_{2} \mathrm{O}, \mathrm{O}_{-} 1$, if the serpentinization at moderate to high temperatures has been largely studied in the field as in laboratory $[10,11]$, the global assessment remains debated and is highly variable depending of the authors [12] for a review of the various estimates). Serpentinization at lower temperatures is observed in the ophiolitic contexts [13], tested in laboratory [14] and through models $[15,16]$. However, the overall assessment and the kinetic of this redox equation (roughly $3[\mathrm{FeO}]+\mathrm{H}_{2} \mathrm{O}=>\mathrm{Fe}_{3} \mathrm{O}_{4}+\mathrm{H}_{2}$ ) remain also poorly known. They appear to be strongly dependent on the temperature but also on the presence of catalyzers [17]. Nevertheless, the Iron oxidation is the more probable source of many of the observed $\mathrm{H}_{2}$ onshore emanations, it is largely present associated with Silicon and Magnesium within the olivine and orthopyroxene in the oceanic crusts. Oxidation of other minerals such as biotite [18] or any other iron-rich mineral could also take place in nonoceanic context and actively participates to the $\mathrm{H}_{2}$ flux. Values up to $100,000 \mathrm{t} \mathrm{H}_{2} / \mathrm{km}^{3}$ of granite have been quantified for the granite in the Rhine Graben by these authors. Sulfur oxidation could be also play a role $\left(\mathrm{H}_{2} \mathrm{~S}+2 \mathrm{H}_{2} \mathrm{O}=>\mathrm{SO}_{2}+3 \mathrm{H}_{2}\right)$ and liberate large quantities of hydrogen offshore as onshore, i.e., above oceanic and continental crusts [9]. For other authors, the water radiolysis within the lower crust is another important $\mathrm{H}_{2}$ source $\left(\mathrm{O} \_2\right)$ which could be at least within the same range of value in term of $\mathrm{H}_{2}$ generation as the oxidation processes [19]. For the researchers who consider that the main $\mathrm{H}_{2}$ source is the degassing of the primordial $\mathrm{H}_{2}$ of the solar system $\left(\mathrm{O} \_3\right)$ the reserves are infinite at the human scale [20,21]. 
Within the C_1 and C_2 contexts the oxidation of $\mathrm{Fe}, \mathrm{Mg}$ or $\mathrm{S}$ rich materials has been largely described and is roughly accepted as the main source of $\mathrm{H}_{2}$. The question remains more debated in the $\mathrm{C} \_3$, the intracratonic basins where large quantities of $\mathrm{H}_{2}$ have been measured. We consider that the O_1 is the more probable, it means that the $\mathrm{H}_{2}$ may come from water/rock interactions in the crust. Knowing the kinetics of these reactions will be key for the $\mathrm{H}_{2}$ production since we are talking about a flow and not about fossil resources; research is active in that domain [17]. Nevertheless, we will leave the question of origin and flow rate open, they are not the topic of this article, and discuss the favorable geological settings and the surface evidences which indicate that a $\mathrm{H}_{2}$ generation could be currently active in a given area. In many places, ten to a few hundred meters wide natural depressions, corresponding to vegetation gaps, have attracted the attention of researchers. Very often their soils contain high ratio of hydrogen. They can therefore be good proxy candidates for $\mathrm{H}_{2}$ exploration.

These depressions, often called fairy circles have already been studied in Russia, USA, and Brazil [8,22-24], see Figure 1. We will use here the wording fairy circles, shorted and more illustrated than "depressed rounded structures", some are using "witch circles", this is an arbitrary choice. The wording fairy circle is also largely used by the biologists who observed also these vegetation gaps and in Namibia researchers suspect gas escapes to explain them $[25,26]$. In Brazil the study of the microorganisms has been done to confirm the link between the surface and subsurface processes [27], it remains a hypothesis in few other places.

In this paper after a state of the art on the knowledges of gas escape structures, we will present new data acquired in Brazil and South Australia and compare them to other basins located southwestward in Australia. Exploration for $\mathrm{H}_{2}$ is not yet active in Australia but the geology being very favorable with similarities to the prospective zones of Mali or Brazil, we undertook a global large-scale study to define the potential $\mathrm{H}_{2}$ emitting basins from literature data set. Those data have been interpreted, or reinterpreted, in the frame of the knowledges developed in Brazil and Russia.

\subsection{Gas Escape vs. Deep Accumulation}

Oil seeps or gas seeps are proxies for exploration in the Oil and Gas (O\&G) industry. They are the proof, at low cost, that hydrocarbons (HC) are generated or eventually accumulated, somewhere in the vicinity. It is one of the tools used by the O\&G industry to derisk prospects. For pessimist explorationists it may be seen as the proof that the top seal is not good enough and that HC leakages are active. However, it does not prevent the possibility of a transient accumulation, whose leaking is comparable to its supply. Hundred years ago, O\&G exploration started near, and with the only use of, surface evidences, which happened to be successful; it seems reasonable to start the $\mathrm{H}_{2}$ exploration with a basin scale study of the $\mathrm{H}_{2}$ surface emanations. Being a low cost approach, it should guide where to acquire more expensive subsurface data. Potentially, surface, or near surface, acquisition and monitoring will also help to better define the transport mode of the $\mathrm{H}_{2}$ in subsurface.

When a non-negligible quantity of gas escapes from the subsurface, it usually affects the ground: offshore, the so-called pockmarks, or eye structures, are very common, mud volcano are also observed and now, onshore, degassing structures are reported in an increasing number of basins including Russia [8], USA [22], and Brazil [23,27]. Offshore, $\mathrm{H}_{2}$ emanations are reported along the mid-oceanic ridges through carbonated or sulfured chimneys [28]. To the best of our knowledge, offshore pockmark corresponding to $\mathrm{H}_{2}$ emanations have not been described even if $\mathrm{H}_{2}$ hydrates have been observed [29]. 


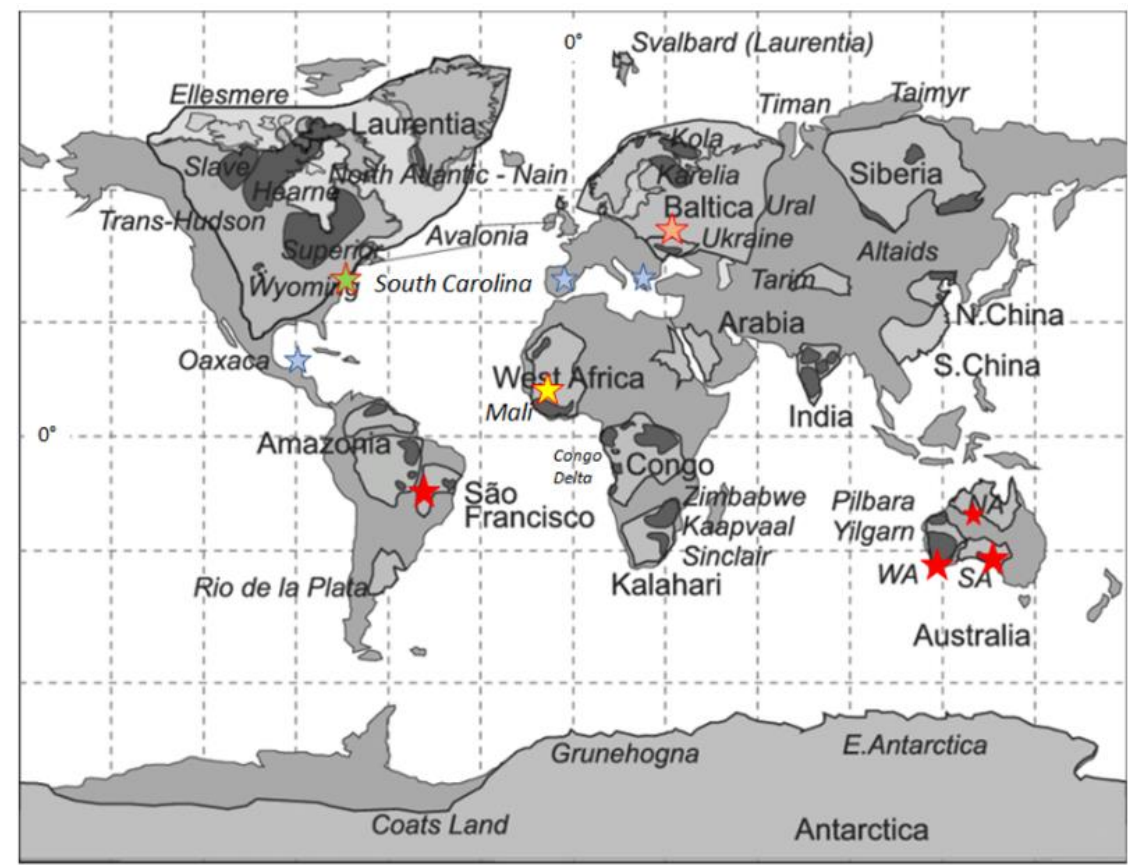

Figure 1. Location of the depressions studied in this paper. Red stars represent the places in Brazil and Australia where new data are presented, for the other locations we have used the published data in yellow Mali [4], in green South Carolina [22] and in orange Russia [8]. The dolines cited in the paper are in blue (Spain, Yucatan and Greece). Map background: Precambrian continents and cratons of the world in their present-day locations. Light gray shading: Proterozoic areas, dark slate gray: Archaean basement, modified from [30].

The upward migration of gas to the surface has been mainly studied thanks to the $O \& G$ industry data. HC gas seeps are the marks of the presence of gas in the subsurface and related structures (pockmarks, mud volcanoes, vents, etc.) are very common and rather easily imaged with the high resolution bathymetry and 3D seismic data now available (see, for instance, [31] and references therein). The 3D-images clearly show that the gas escapes through narrow conduits from the reservoir, which very often, offshore, is the free gas zone below the hydrate layer or, alternatively, a shallow reservoir such as a sandy channel [32]. Sometimes, especially in the case of mud volcanoes, the gas is thermogenic and may come from much deeper areas, up to few kilometers [33]. If we exclude these deep cases, the conduits are roughly vertical and may, or not, correspond to small faults even in young, and so uncompacted, sediments. Each one is active for a short period of time and when the sedimentation and subsidence is going on, the traces of the previously active pipes, the feeding conduits of each pockmark appear as "trees" shaped. They do not intersect, some authors even notice a kind of chimney-free zone around them [31]. This "nearest neighbor distance" is between $500 \mathrm{~m}$ and $3 \mathrm{~km}$ in the offshore Namibia case published by [34]. However, since the spatial resolution of the seismic data is limited, small pockmarks within or close to a large one can be not visible and omitted in their approach. Authors differ on the exact mechanism of the creation of these chimneys, but they all agree on the fact that it is a catastrophic event related to fracture propagations at the top of the reservoir/free gas zone. The pipes show an episodic growth [35]. When the water is gas saturated (ratio that depends on the depth), the gases migrate in a gas phase in a water saturated medium of the recent and non-consolidated sediments. Diameter size ranges from $50 \mathrm{~m}$ to $900 \mathrm{~m}$ (compilation done by [35] on 10 case studies) and the depth of the pockmarks on the seabed floor may be up to $40 \mathrm{~m}$ deep; the height of the pipes in that compilation ranges from a few ten of meters to $1.5 \mathrm{~km}$.

The fairy circles, on the other hands, are never very deep depressions, being less than $10 \mathrm{~m}$ in our data base. They may intersect and seems often to grow by leakage. The reason 
for the differential subsidence that creates depression is unclear and is out of the scope of this paper. We will only describe the ground characteristics of these structures on the studied cases. Soils being usually not fully water saturated the transport mode of the gas $\left(\mathrm{CH}_{4} \mathrm{Or} \mathrm{H}_{2}\right.$, respectively) toward the surface differs, however one may suspect that $\mathrm{H}_{2}$ emitting structures as the $\mathrm{CH}_{4}$ emitting pockmarks are the proxy of gas reservoirs in subsurface and so are worthy of mapping in the framework of an early exploration phase.

\subsection{Methods}

In this paper we will present two different types of results:

- The characterization of the fairy circles in known $\mathrm{H}_{2}$ rich zones largely based on the mapping of the emissive structures on satellite images.

- A first application of this proxy of $\mathrm{H}_{2}$ presence within the soil in two areas where exploration has not yet started, located in the southwestern part of Australia.

Two kinds of data may prove the presence of natural hydrogen in a basin, the $\mathrm{H}_{2}$ content in the soil near the surface and the fact that a large proportion of $\mathrm{H}_{2}$ has been measured by well tests in the gas accumulations in the subsurface. In the studied areas, gas in the soil have been measured in Brazil and Russia and $\mathrm{H}_{2}$ has been found in drilled prospects by the O\&G industry in two basins in Australia (session 2). We will describe the surface structures, the fairy circles, their size, density, and morphology and extract the characteristics common to the various $\mathrm{H}_{2}$ rich areas that may be used as a proxy of $\mathrm{H}_{2}$ presence. These structures correspond commonly to vegetation gap and are lightly depressed, of a few meters.

In order to compare the size in the various areas, an equivalent radius (or diameter) is presented: to obtain it, we digitized the zone were the vegetation is affected, and we computed the radius of a perfect circle that would have the same surface. The diameter distributions will be displayed as well as the average and mean values. The depth and the slope have been computed, the accuracy of these values is depending on the available Digital Elevation Model (DEM), in the places where we had the opportunity to do direct measurements the error was less than $10 \%$. In the areas where we did not have enough data to be confident we did not show or discuss these depth measurements.

$\mathrm{H}_{2}$ flow toward the surface is clearly not the only process that may result in depression of the ground surface; it is out of the scope of this paper to do an exhaustive or statistical approach of all them but we will propose measurements that can be easily done to discriminate karstic dolines from fairy circles (session 3).

In some places, $\mathrm{H}_{2}$ accumulations have been found in subsurface in areas where the surface morphology does not display any of these characteristics. It is the case for one of the studied Australian basins, above the accumulation in Mali, and in New Caledonia. Some explanations will be proposed in the discussion.

In a second part (sessions 4 and 5) we will compare data from areas where $\mathrm{H}_{2}$ presence is known from other areas, especially in Australia where similar structures are observed. This new proxy could be used to prepare, focus and be confident before scheduling field work more expensive and time consuming but also sometime very difficult when the area is poorly accessible (distance, lack of roads, and political issues). The strategy proposed for the early exploration phase will be discussed in the conclusions session 6 .

\section{Data Set of $\mathbf{H}_{2}$ Emitting Structures}

The old cratons host many of the $\mathrm{H}_{2}$ emitting structures, even if they have been disregarded up to recently, but it is out of the scope of this paper to list them. The improvement of the free access satellite images, such as Google Earth Pro, allows easy mapping of these fairy circles. In addition, high $\mathrm{H}_{2}$ concentration has been noted in mines, wells, fluid inclusions along others. The maps published by Zgonnik [21] clearly show that the density of known sites, where concentration of $\mathrm{H}_{2}$ in the gas analyses exceeds $10 \%$, is still mainly related to the measurement density. Geology, that we may expect to be the key factor, 
is today of second order since the data are still limited. The fairy circles are visible on satellite images, and as such can easily be mapped without field acquisition.

\subsection{Brazil}

Surface $\mathrm{H}_{2}$ emissions in the Minas Gerais State have been noticed for a couple of years, and punctual data have been collected. Their variabilities have emphasized the fact that the amount of gas in the soil is changing versus time, location in the structure, and depth. In order to understand these variabilities long term monitoring has been carried out with the Parhys permanent sensors developed by ENGIE Lab Crigen. The first months of results have shown for the majority of the $\mathrm{H}_{2}$-sensors, a daily variation but also much larger sporadic pulses for some of them [23]. The full data set that now covers more than 2 years confirmed this tendency but also highlighted the importance of the pulses during which the amount of $\mathrm{H}_{2}$ in the soil can saturated the sensors [24]. The few hundreds of ppm that escape from the soils with the near $24 \mathrm{~h}$ frequency may be seen as a secondary effect of the saturation of the $\mathrm{H}_{2}$ site, after a large pulse is liberated. These changes in $\mathrm{H}_{2}$ soil concentration may be related to biologic activity [27], external causes such as the atmospheric pressure [36] or retention processes in the soil such as adsorption/desorption [37]. This long term and dense monitoring of fairy circles has highlighted an important point, already noticed by previous authors in other contexts $[8,22]$ one cannot conclude that a structure is not emitting $\mathrm{H}_{2}$ without several weeks of monitoring. The structures may be without $\mathrm{H}_{2}$ for a few days and nevertheless be active on a monthly basis. In the agricultural areas, the archive images make it possible to see often the reappearance of the rounds erased by the ploughing, the appearance, or the disappearance, of new structures is rarer to observe.

These structures are the place of large $\mathrm{H}_{2}$ emissions. The published data corresponding to monitoring of two adjacent fairy circles [23,24] showed a flow of 0.03 and $0.04 \mathrm{~m}^{3} /$ day $/ \mathrm{m}^{2}$ that means $3 \mathrm{~g}$ of $\mathrm{H}_{2} /$ day $/ \mathrm{m}^{2}( \pm 10 \%)$, i.e., $3 \mathrm{t}$ of $\mathrm{H}_{2} /$ day $/ \mathrm{km}^{2}$. It is in the same range of value as that proposed by [22] for the structures in the USA.

\subsubsection{São Francisco Geological Setting}

The space images and digital elevation models of Brazil display many of the circular structures similar to the ones that have been monitored. They are present in different basins in the country, but we only discuss here a few of the many ones located in the São Francisco Basin.

Bounded by two orogenic belts, the São Francisco Basin is a N-S oriented structure that corresponds to a double foreland basin, the Brasilia Belt westward and the Araçuai Belt eastward. Both were created during the Brazilian Orogeny, at the end of the Proterozoic [38].

The stratigraphic column includes rocks from Archean metamorphic basement $(>1.8 \mathrm{Ga})$, they can reach up to $7 \mathrm{~km}$ in thickness, and ends with the Neoproterozoic Tres Maria Formation (576 Ma. old) of the Bambui Group. The area is rich in minerals and many mines are active. Iron rich material, such as the Banded Iron Formation (BIF) are present in the South of the basin, and could be a potential source of $\mathrm{H}_{2}$. These facies are outcropping in the thrusts eastward (especially in an area called Quadrilatero Ferrifero) but are also very likely present below the area where $\mathrm{H}_{2}$ is escaping since a large magnetic anomaly has been recognized [38,39].

\subsubsection{Statistics on Size Distributions of the Fairy Circles}

Gas measurements in the soil, done with a portable gas detector the GA $5000^{\circledR}$ between 2016 and 2019 allow us to detect concentration of $\mathrm{H}_{2}$ in the soil in various locations (turquoise dots Figure 2) as well as to measure the $\mathrm{CO}_{2}, \mathrm{CH}_{4}, \mathrm{O}_{2}$, and $\mathrm{H}_{2} \mathrm{~S}$ contents. Outside of the depressed and vegetation free structures there is no $\mathrm{H}_{2}$ in the soil; within the structures, the $\mathrm{H}_{2}$ content is variable. A statistical approach of the size and shape of these fairy circles has been carried out in 3 zones, blue, red and yellow in the Figures 2 and 3 . 


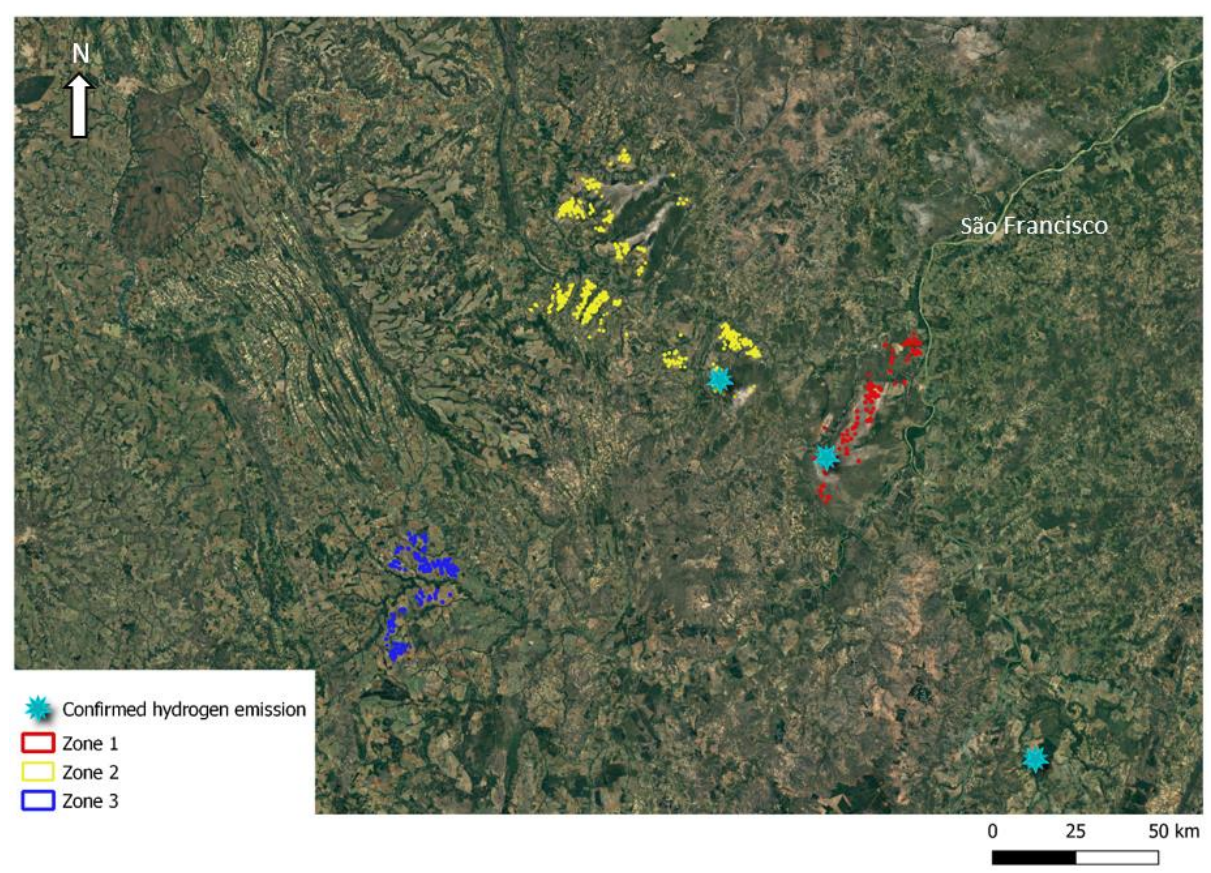

Figure 2. São Francisco Basin, Brazil. The area where $\mathrm{H}_{2}$ emissions have been already measured are presented with turquoise stars. Each corresponds to a set of measurements (from 10 to 100). The location on the fairy circles mapped in the present work are: in red the area called Brazil_1 here. It is where the monitoring is taking place for 2 years $[23,24,27]$, in yellow: Brazil_2, in dark blue: Brazil_3.

The red one, Brazil_1, corresponds to the area where permanent monitoring took place from 2018 to 2020 [23,24]. The results of size distribution are presented Figure $4 \mathrm{~A}$. In total 86 structures have been mapped (Figure 3A) and the full zone affected by their presence is about $500 \mathrm{~km}^{2}$ large. Globally there is no preferential shape for the structures neither clear logic within their spatial repartition within the small hills trending N20. The measured depths range from 1 to $7 \mathrm{~m}$ (depression) and they increase with size. The correlation depth/size is depth $=0.013 \times$ diameter. We may note a bimodal repartition of the size distribution with two maxima on the equivalent diameters, around 175 and $325 \mathrm{~m}$ (Figure 4).

The second zone, Brazil_2, where the structures have been mapped in yellow is located at about $35 \mathrm{~km} \mathrm{NW}$ of the previous one with 406 structures mapped in this $321 \mathrm{~km}^{2}$ large zone (Figure $3 \mathrm{~B}$ ). Emission of $\mathrm{H}_{2}$ have been measured in about 15 of these structures with concentrations in the soils of few hundreds of ppm. The structures are mainly located in small hills between the rivers, with the average elevation between the bed of the rivers and the white area at the top of the hill of about $25 \mathrm{~m}$. The "white" appearance in the satellite images came from the white sand present there. On average, the structures present the same characteristics (Table 1) but the sizes are a little bit more diversified with small structures (radius minimum of $19 \mathrm{~m}$ ) and large ones (radius maximal of $390 \mathrm{~m}$ ). There is no preferential direction in the shape of the structures. The size distribution is also very similar to the one of the red area however the $175 \mathrm{~m}$ pick is less pronounced and the main pick is around $275 \mathrm{~m}$ in diameter (Figure 4). 

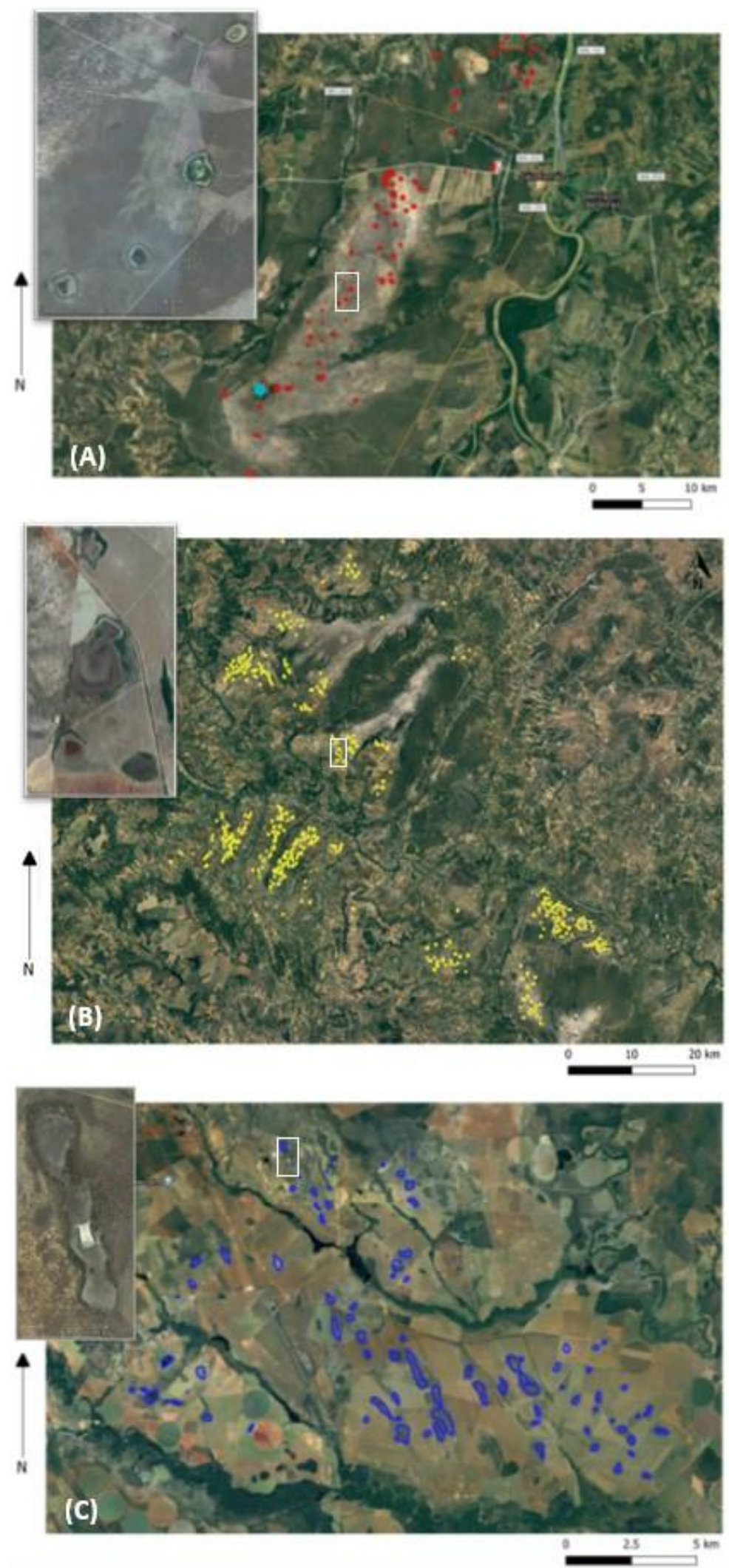

Figure 3. Mapping of the fairy circles in the 3 studied zones in the São Francisco Basin (see location Figures 1 and 2). (A): zone Brazil_1; (B) zone Brazil_2; (C) zone Brazil_3. Insert is a zoom on one of these depressions located by the rectangle on the large image. 


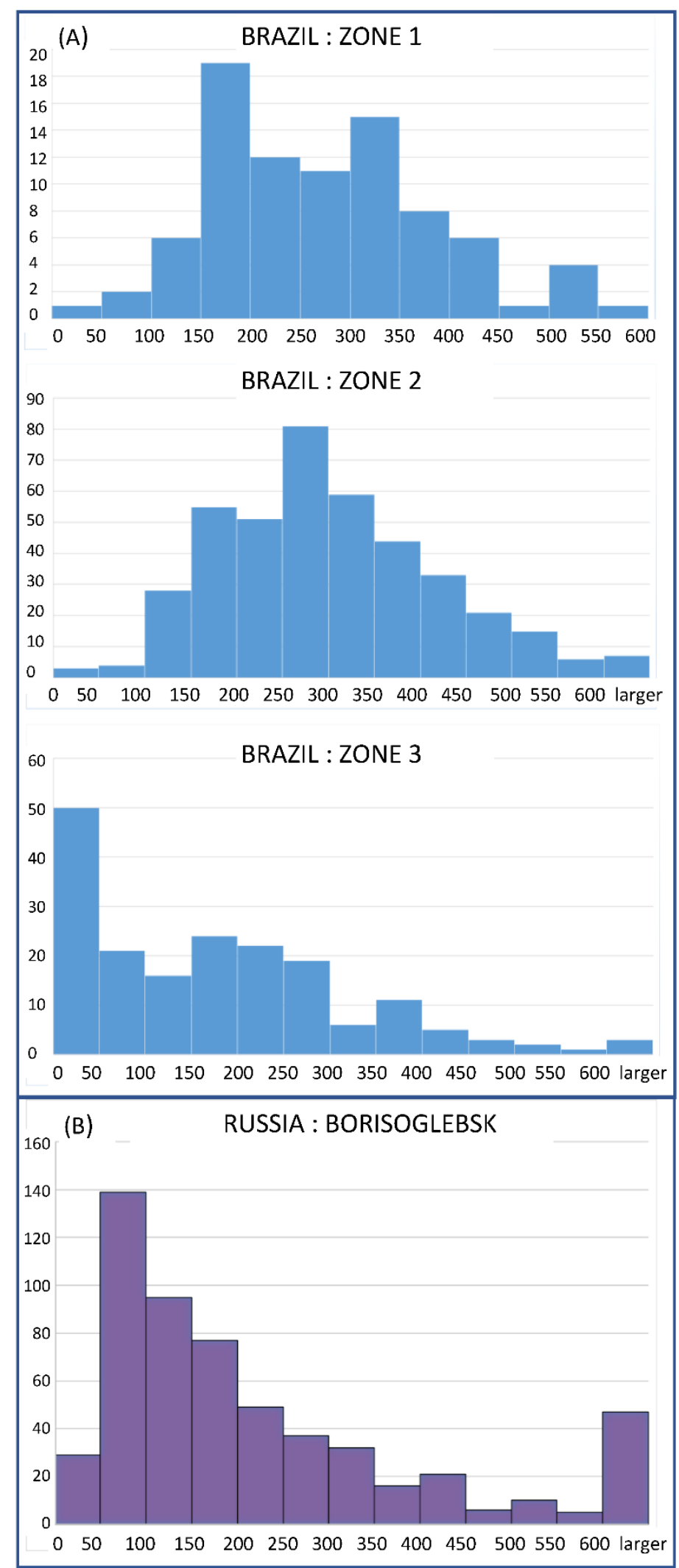

Figure 4. Diameter equivalent statistic on the three zones in Brazil (A) and Russia (B). Horizontal axis represents the equivalent diameters, values in meters, the vertical axis is the number of structures per interval of $50 \mathrm{~m}$. The total number that is variable depending of the area, see Table 1 . The Russian data are from) [8] but shown using the same scale as for Brazil. All the large depressions, with a diameter larger than $600 \mathrm{~m}$, are grouped within the last column. 
Table 1. Comparison of the characteristics between the 3 mapped areas in Brazil and the Borisoglebsk area (Russia), this last zone has been studied by [8].

\begin{tabular}{ccccc}
\hline & Brazil-1 & Brazil-2 & Brazil-3 & Russia \\
\hline Number of mapped structures & 86 & 406 & 183 & 540 \\
Emitting Surface $\left(\mathrm{km}^{2}\right)$ & 5.9 & 33.8 & 7.5 & 77 \\
Density (foot print) & $1.3 \%$ & Global 1\%/5\% & $2.8 \%$ & na \\
Average equiv radius (m) & 138 & 151 & 89 & 132 \\
Min equiv radius (m) & 43 & 19 & 7 & 9 \\
Max equiv radius (m) & 290 & 390 & 347 & 1250 \\
Ratio depth/diameter & 0.013 & 0.011 & 0.008 & 0.007 \\
\hline
\end{tabular}

The third zone, Brazil_3, is located southeast of the red one, at $130 \mathrm{~km}$ of distance. It is $200 \mathrm{~km}^{2}$ large. One hundred eighty-three structures have been mapped in blue and the distribution is slightly different (Figure 3C). If the biggest structures have roughly the same size, the smallest ones have only a few meters of radius and the size distribution shows a large majority of small structures. The shape is elongated along a N150-160 axis but individually the structures do not have an ellipsoid shape. Figure $3 C$ shows that the structures are very numerous on few, rather parallel, zones also N150-160 oriented and they grew by merging with the closest ones on this rosary. This direction corresponds to the one of the structural highs that outcrop north of the area, suggesting that they are lined up with leaking faults. As in the two other zones, the structures are in the hills between the rivers. That is coherent with the fact that clayey levels may be present in the river beds and channel the upcoming gas to the more permeable zones [27]. The ratio between the depth of the structures and their diameters is lower than the two others areas $(0.008)$ but remains in the same order of magnitude of $1 \%$.

To summarize the data from the São Francisco Basin, the fairy circles have size between few to $400 \mathrm{~m}$ as equivalent radius, the average area of the 675 mapped structures is $70,000 \mathrm{~m}^{2}$ and the average radius of $133 \mathrm{~m}$. In that area there is no preferential shape for the structure but groups of structures may follow geomorphological trends. The depth/diameter ratio seems to be rather "constant" on the range of $0.8 \%$ and the footprint is low and varies from 1 to $5 \%$. The sum of the fairy circle areas is $47.2 \mathrm{~km}^{2}$. If the average flow of $\mathrm{H}_{2}$ is the same as the one measured on the monitored structures (located in Brazil_1), 3t/day $/ \mathrm{km}^{2}$, it means that about $140 \mathrm{t}$ of $\mathrm{H}_{2}$ is leaking per day from this part of the São Francisco Basin. This large amount justifies the start of the exploration which is taking place in this area.

We will now compare these numbers to another $\mathrm{H}_{2}$ rich zone in Russia.

2.2. Russia

\subsubsection{Geological Setting of the Borisoglebsk Area}

The region is part of the ancient Russian platform and its basement is composed of deformed metamorphic and igneous Precambrian rocks, including partly Archean rocks. The sedimentary cover is almost undeformed and is lying sub-horizontally on the Precambrian basement. These sediments range in age from Devonian to Tertiary and their thicknesses are increasing monotonously from WSW to ENE from 0 to about $900 \mathrm{~m}$. The uppermost sediments are fluvioglacial morainic loam; however, in all the sites studied by [8], the uppermost sediments correspond to recent unconsolidated granular sediments. The few wells drilled to Precambrian basement revealed rocks of lower Proterozoic, such as schists, metasandstones, metasiltstones, metabasalts, metadacites, quartz porphyry, gneiss, amphibolite, and tremolite actinolite rocks [8].

\subsubsection{Statistics on $\mathrm{H}_{2}$ Emitting Structure Morphological Characteristic}

South-east from Moscow, Larin and its coauthors [8] described many $\mathrm{H}_{2}$ emitting depressions and their non-constant behavior in term of gas leakage. To the best of our knowledge it was the first paper dedicated to these kinds of structures even if many 
previous papers highlighted the presence of $\mathrm{H}_{2}$ in various locations (fault zones, mines, etc.). Thanks to Slava Zgonnik, coauthor of the Larin's et al paper, we obtained access to its data base of fairy circle maps and we analyzed it with the same approach than those used in Brazil. Results are shown in Table 1 and in Figure 5. In terms of size, the average (equiv. radius $132 \mathrm{~m}$ ) and minimum values (equiv. radius $9 \mathrm{~m}$ ) are very close to those found in the São Francisco Basin. The main difference is the existence of few very large structures, with a radius larger than $1 \mathrm{~km}$. On the size distribution representation, (Figure 4), we limited the range in order to have the same scale as the Brazilian cases. We noted a unimodal distribution. In the [8], these data are presented in a log scale extending up to the largest one (equiv radius $1250 \mathrm{~m}$ ) giving the feeling that the very small structures are the most numerous (see [8] (Figure 4)). It is the case but the linear scale chosen here allows better separation of the structures smaller than $50 \mathrm{~m}$, which are not so numerous, from the 50-100 range ones, which are largely the most numerous.

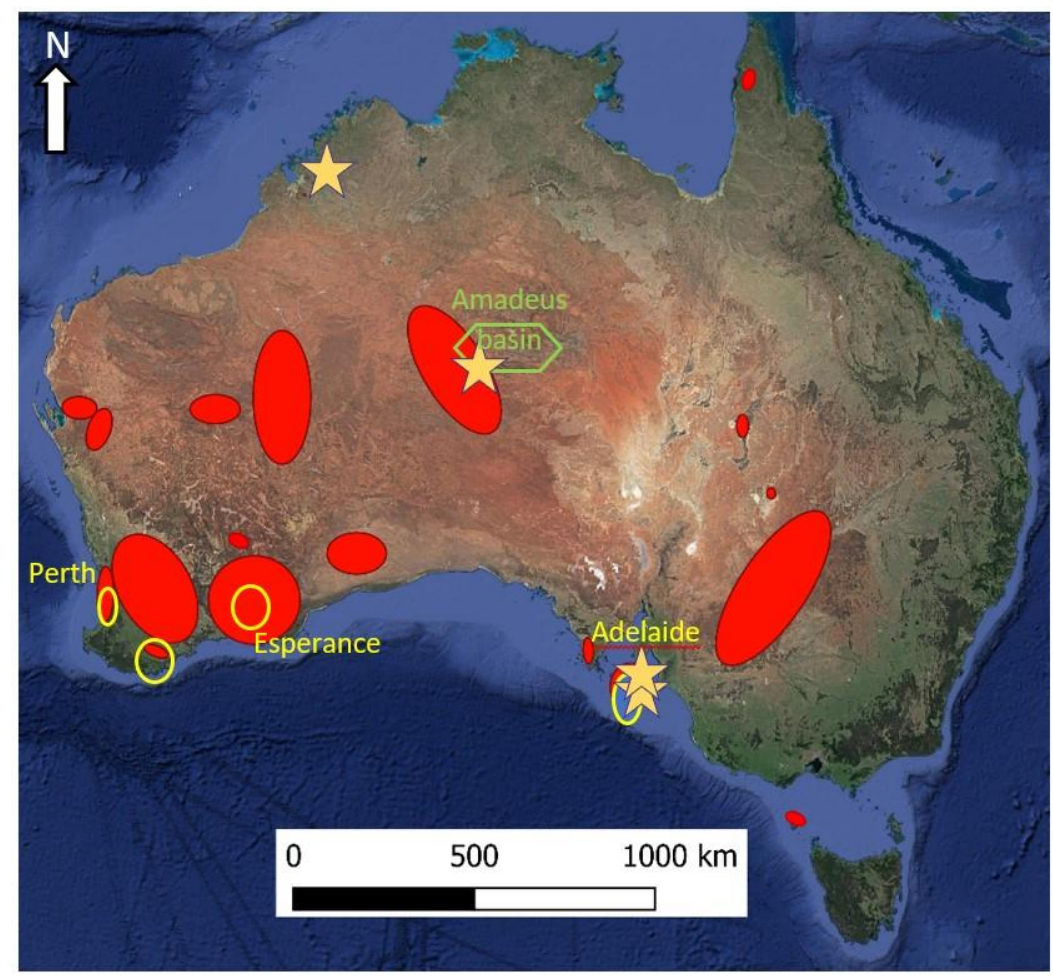

Figure 5. Location of the areas with many circular depressions in Australia (red areas). The yellow stars are the location of the wells that found $\mathrm{H}_{2}$, the yellow circles highlight the areas where depressions that look like fairy circles can be observed and where statistic has been done in this study.

In terms of depth, some depressions are invaded by water and the zone is full of farms and cultivated fields, so the depth we measure without having access to the water depth in the lakes is likely a minimum. From our measurements the average ratio depth/size is 0.007 for the small structures. For the large one, over $1 \mathrm{~km}$ the depth does not increase and lack an apparent correlation with the size. We should also note that some of the structures are not simple soft depressions and small reliefs may exist. We do not know if they are natural, i.e., if the subsidence took place on a ring, or if they are artificial and due to human's earthwork. The total area of these fairy circles is about $77 \mathrm{~km}^{2}$, which would correspond to a daily hydrogen flow seeping out of $70 \mathrm{t}$ using the average $10,000 \mathrm{~m}^{3} / \mathrm{d} / \mathrm{km}^{2}$ estimated by [8].

To conclude, the Brazilian and Russian fairy circles have similar sizes and size distributions and their depth/diameter ratio is low as in Brazil, less than 0.01 . 


\subsection{Australia}

Australian geology has many characteristics that present an optimistic view of its natural $\mathrm{H}_{2}$ resources. Few wells drilled by the $O \& G$ industry already confirmed it.

\subsubsection{Geological Setting}

The Australian basement could be divided into three cratonic elements, the North, South, and West cratons (Figure 1). The NAC (North Australian Craton) is composed of several Paleoproterozoic orogens with some Neoarchean inliers. Paleoproterozoic orogens are metasedimentary sequences intruded by granites. These orogens are bounded by late Paleoproterozoic to Phanerozoic cover sequences [40]. The WAC (West Australian Craton) is composed of the Pilbara Craton, the Lenburgh Terrane and the Yilgarn Craton which are Archean to Proterozoic [41,42]. Southward, the SAC (South Australian Craton) is composed of the Gawler Craton, the Broken Hill Block, the Curnamona Province, and the Adelaide area which are also Archean to Proterozoic.

The SAC (South Australian Craton) and the NAC (North Australian Craton) are separated by the Musgrave Province. The west margin of the SAC is separated from the WAC (West Australian Craton) by the Albany-Fraser Orogen at 1.30-1.10 Ga. The NAC and the WAC are separated by the Rudall Complex [43]. The SAC craton records an extended geological history from 3.15 to $1.45 \mathrm{Ga}$. The oldest rocks in this craton are granitic gneisses from 3.25 to $3.15 \mathrm{Ga}$, which could form the basement of a large part of Gawler Craton [43]. The sediments that cover this craton are between 2 and $8 \mathrm{~km}$ thick [44,45].

The Australian space images display an impressive number of sub-circular depressions. On the Figure 5 the red area highlights the zones where we observed them and the yellow ellipses show where we did some mapping. Given the size of the country the list is perhaps not exhaustive. The highest density of structures is located above the Archean Yilgarn Craton East of Perth as recently noticed by [46].

\subsubsection{Wells with $\mathrm{H}_{2}$ Measurements}

From what we know, data on $\mathrm{H}_{2}$ concentrations in soil in Australia are still missing, or unpublished, but high $\mathrm{H}_{2}$ concentrations have been reported in various wells, drilled by the oil and gas companies (Figure 5). In the Adelaide area, two wells drilled in 1922 on Kangaroo Island and in 1931 on the Yorke Peninsula discovered an "inflammable gas" which, after analysis, revealed very high hydrogen levels of up to $84 \%$ (Table 2) of the total composition of the gas [47]. The results of the tests done at various depths in the wells are presented Table 2. Since there is oxygen in the published data, we did a correction considering that its presence is due to the air contamination, removing the atmospheric part of nitrogen. Corrected values are listed below the published ones.

In Kangaroo Island, the well drilled by American Beach, located approximately $35^{\circ} 48^{\prime} \mathrm{S}, 137^{\circ} 50^{\prime} \mathrm{E}$ (Figure 6A), found Precambrian micaschist from $100 \mathrm{~m}$ to the TD (290 m). The two production tests were both carried out within this formation. Within the Yorke Peninsula, the well drilled by Minlaton Oil Prospecting Synd. is located south-east from Minlaton town $\left(35^{\circ} 02 \mathrm{~S}, 137^{\circ} 36 \mathrm{E}\right)$, see Figure $6 \mathrm{~B}$, the formations are carbonated except the basal Cambrian which is more shaly and ranges from Cambrian (limestones) to Upper Precambrian (also limestones). The locations are not very well defined because these wells have been drilled roughly one century ago, we do not have the original information and we relocated them based on the description given in the paper (the location error may reach one kilometer). In the original paper the authors reported a discussion about the origin of the gas, they exclude the "marsh gas", name apparently given at that time to the gas issued from the organic matter with a biological generation, and the authors concluded that it cannot be the case for the hydrogen found in the wells. 
Table 2. Gas analyses from the test of the wells) [47], CO and ethylene have been also measured, their concentration is null. In italic: same analyses, after our correction of air contamination, assuming the standard atmospheric ratio $\mathrm{O}_{2} / \mathrm{N}_{2}$ for the air fraction of the analyzed gases and considering, as usual, that all the oxygen come from the air and that the only contamination is atmospheric.

\begin{tabular}{ccccccccc}
\hline & \multicolumn{3}{c}{ Yorke Peninsula } & \multicolumn{3}{c}{ Kangaroo Island } \\
\hline Depth $(\mathrm{m})$ & 240 & 240 & 262 & 262 & 262 & 508 & 187 & 288 \\
\hline Original values & & & & & & & & \\
\hline $\mathrm{CO}_{2}(\%)$ & 0.8 & 0.2 & 0.8 & 0.8 & 0.6 & 0 & 5.3 & 0.52 \\
\hline $\mathrm{O}_{2}(\%)$ & 0 & 0 & 3.2 & 2.4 & 3 & 1.2 & 4.3 & 3.55 \\
\hline $\mathrm{H}_{2}(\%)$ & 74 & 76 & 60 & 64.4 & 60 & 84 & 51.3 & 68.64 \\
\hline $\mathrm{CH}_{4}(\%)$ & 7.5 & 7.5 & 5.4 & 7 & 5.6 & 0 & 2.6 & 4.68 \\
\hline $\mathrm{N}_{2}(\%)$ by difference & 17.7 & 16.3 & 30.6 & 25.4 & 30.8 & 14.8 & 36 & 22.61 \\
\hline Air corrected values & & & & & & & & \\
\hline $\mathrm{CO}_{2}(\%)$ & 0.8 & 0.2 & 1.0 & 0.9 & 0.7 & 0.0 & 6.8 & 0.6 \\
\hline $\mathrm{H}_{2}(\%)$ & 74.0 & 76.0 & 71.3 & 73.1 & 70.5 & 89.3 & 65.6 & 83.3 \\
\hline $\mathrm{CH}_{4}(\%)$ & 7.5 & 7.5 & 6.4 & 7.9 & 6.6 & 0.0 & 3.3 & 5.7 \\
\hline $\mathrm{N}_{2}(\%)$ & 17.7 & 16.3 & 21.3 & 18.1 & 22.3 & 10.7 & 24.3 & 10.4 \\
\hline
\end{tabular}

Much more recently, wells located in the Amadeus Basin (Central West part of Australia, see Figure 5 and drilled by Santos also found $\mathrm{H}_{2}$ [48]. The Amadeus Basin is located in central Australia, mainly in the Northern Territory, with a surface around 170,000 km². It is composed of neo-Proterozoic and early Paleozoic sediments, the latest mainly located in the eastern part of the basin. As the São Francisco basin, it is today a double foreland. The E-W oriented fold and thrust belt (Alice Springs Orogeny) affected the full sequence from Cambrian to Devonian and the presence of large evaporitic sequence, early Neoproterozoic age induced important salt tectonics, during the folding. Few tens of exploration wells have been drilled and the northern part of the basin hosts various gas fields whereas the southern part is considered as under explored. In that southern area, the targets for the O\&G industry are conventional structures under the Neoproterozoic evaporitic seal of the Gillen Fm (Cryogenian, about 630 Ma). Both the Mt Kitty-1 and Magee-1 wells, drilled respectively in 2014 and 1992, found gas reach in $\mathrm{CH}_{4}, \mathrm{H}_{2}$, He below the salt the reservoirs are fractured granite and presalt carbonate [48]. The salt is thick and appears to be an effective seal for the $\mathrm{H}_{2}$ and $\mathrm{He}$.

Another well found Hydrogen in NW Australia and its location is presented Figure 5.

Eastward of Perth, wells drilled in the vicinity of a gold mine also confirmed the presence of $\mathrm{H}_{2}$ and abiotic methane [49]. This zone is located north of the Esperance area studied in that paper. Authors also interpreted the $\mathrm{H}_{2}$ generation as due to the water-rock interactions, basalt is present in subsurface.

To conclude, the presence of old Precambrian cratons in Australia suggests that generation of $\mathrm{H}_{2}$ may take place as in Russia, Brazil, and Mali. At least five wells already tested significant $\mathrm{H}_{2}$ concentrations with variable values, near Adelaide and in the Amadeus Basin. Around or in the vicinity of these wells, but also in other basins, fairy circles have been observed. We present now their characteristics. 

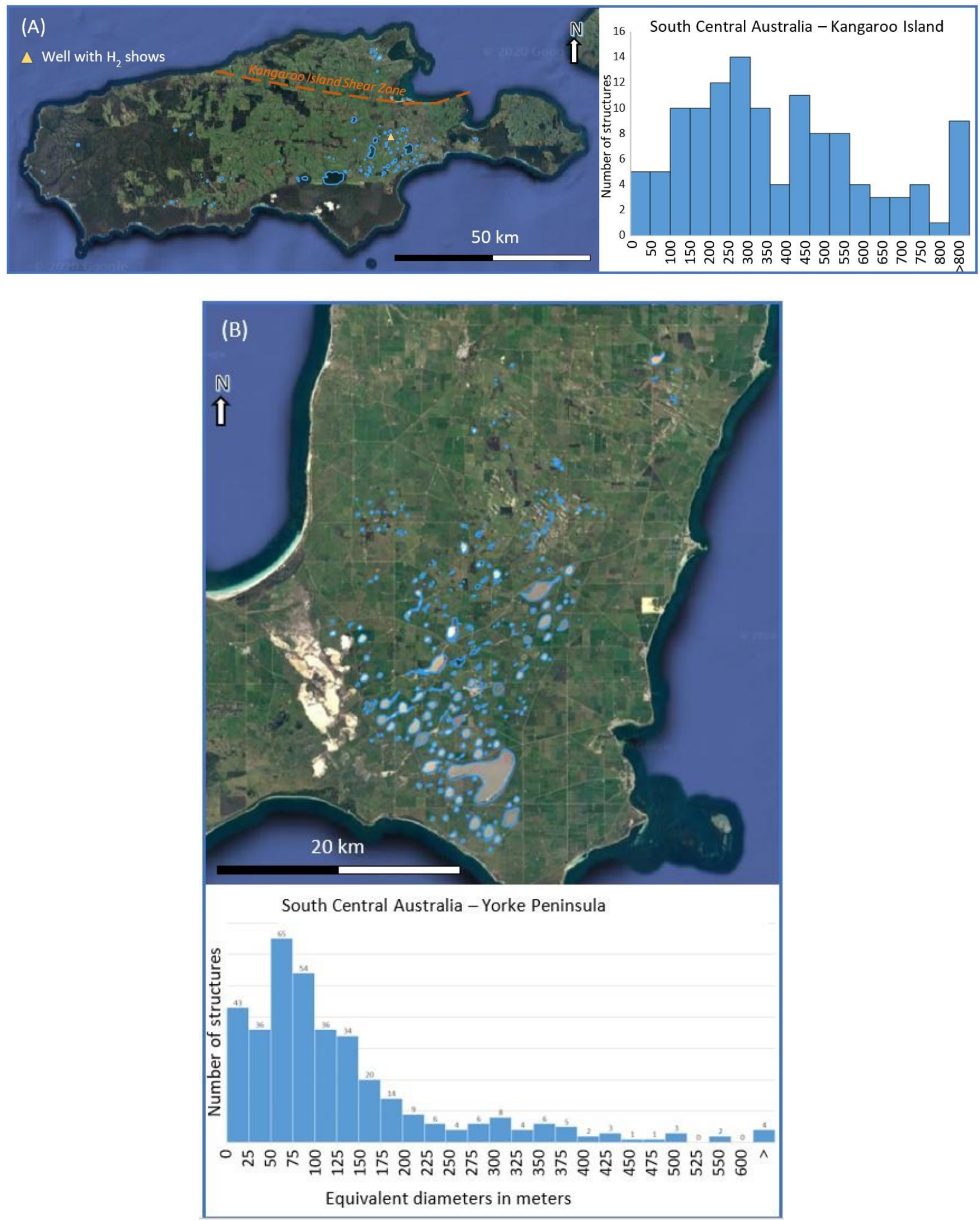

Figure 6. The mapping and the diameter equivalent statistic for the fairy circles in the Adelaide Area, South Australia. (A) (above) Kangaroo Island, (B) (below) Yorke Peninsula. 


\subsubsection{Mapped Structures near Adelaide}

Fairy circles are observed in the Kangaroo Island and in the Yorke Peninsula (Figures 1 and 5), these areas are located in the SAC and more precisely overlie the Gawler craton. The Island is located on a major accident which is $\mathrm{E}-\mathrm{W}$ trending at this location. This main thrust is bending and becomes N-S at the level of Adelaide. The northern central peninsula consists on shallow marine Cambrian Kangaroo Island Gp, thrusted above the Gawler Craton. The Neoproterozoic in that area, south in the Island and east in the Adelaide peninsula consists of the Kanmantoo Gp, also Cambrian but deep marine which is overlaying the craton. On the Kangaroo Island there are numerous structures that are fairy circles like, mainly above the Kanmantoo Gp (522 Myr) [45] but not exclusively.

The density of the structures increases around the well which found $\mathrm{H}_{2}$ within the Precambrian formation (Table 2). Figure 6A shows the maps of these structures as well as their size distribution. We mapped 121 structures, the size varies from $10 \mathrm{~m}$ to $2 \mathrm{~km}$ (radius equivalent) but as it can be seen on the map, there is one single very big structure. Over the island area, the footprint of the fairy circles is $41 \mathrm{~km}^{2}$ representing slightly less than $1 \%$ of the Kangaroo Island $\left(4400 \mathrm{~km}^{2}\right)$. Nevertheless, in the central-eastern quarter where the circles are numerous, this density is over $5 \%$ and more than $10 \%$ around the well.

The zone is highly faulted but the shear zone that separates the North from the South does not correspond to an increase of fairy circle density.

The Yorke Peninsula is also located above the same Gawler craton, locally intruded by magmatic bodies. It is covered by up to $6 \mathrm{~km}$ of Cambrian, mainly carbonated, and locally by a few hundred meters of Permian and some Cenozoic. At the level of the well, there is no recent sediment, the Cambrian is only $100 \mathrm{~m}$ thick and Precambrian limestone's have been found down to the TD [47].

Figure $6 \mathrm{~B}$ shows the 365 mapped structures. The North-South accident that borders the southwestern extremity of the peninsula limits the fairy circles. The density in the affected zone is higher than on Kangaroo Island, about $4 \%$, and there are many small structures. The large ones, as in Kangaroo Island, appear to be formed by the merger of small ones in the area where the density is high. A N-40 trend can be noticed, it corresponds to the Pin Point Fault direction; this fault is an east verging thrust. The sum of the areas of the mapped fairy circles is $47 \mathrm{~km}^{2}$.

\section{Fairy Circles vs. Dolines}

Gas escapes are not the only processes that may create small depressions of the ground visible on space images. Impact craters exist, but they are isolated and therefore cannot be confused with the large set of structures that we are targeting to prove gas escape. Carbonate rocks dissolve, collapse and subside through karstification. This leads to the formation of dolines, which are defined as "small to intermediate enclosed karst depression regardless of genesis or climatic context" [50]. The resulting pockmarked depressions may have the same shapes and range of diameters compared to those of fairy circles.

Dolines have circular to sub-circular plan-shapes with diameters ranging from a few meters to $\sim 1 \mathrm{~km}$. Their sides may be vertical to gently sloping from a few to several hundred meters. It is out of the scope of this paper to do morphological study of karst systems-for further information, see [50,51], and references therein. Figure 7 shows an example of such a void, on the left fairy circles, created by the $\mathrm{H}_{2}$ escape (diameter about $500 \mathrm{~m}$ ) and right two dolines (diameters 280 and $800 \mathrm{~m}$ ) from Spain and Mexico (see location Figure 1). Horizontal size and shape do not allow to separate then, but depth and slope are larger for the karst system. For the about 700 structures mapped in Brazil the depth/diameter ratio is always below $1.5 \%$ and in average lower than $1 \%$ (Figure 3) and the depth itself never exceeds $7 \mathrm{~m}$. In the doline in Spain this ratio is more than $10 \%$ and they are always deeper than $6 \mathrm{~m}$. Often the depressions are full of water so this value cannot be computed, as it is the case for the Mexican example from the Yucatan Peninsula karst system, Figure 7D. The latter features are called "cenotes" which are steep-walled karst depressions, formed by collapse into an underlying, flooded, active cave passage — so the depressions are floored 
by water [51]. The measured depth is the water table $10 \mathrm{~m}$ below the surface in such a typical cenote, the ratio will be so over $8 \%$ which is already quite above the values of the gas escape related structures. Further, another parameter allows us to differentiate both: the slopes at the sides of the depression. For the two dolines, the maximum slopes reach $36 \%$ (case $\mathrm{C}$ ) and 18\% (D) and the averages are, respectively, 16 and $6 \%$. For the fairy circles the maximum is lower than $8 \%$ and the average $3 \%$.

Since the maximum of slope is on the sides of the dolines, usually above water level, we may consider it as the more relevant criterion (Figure 8). In addition, $\mathrm{H}_{2}$ emitting structures in our data base do not have depths greater than $10 \mathrm{~m}$. Another criterion, is that dolines may exist even if there is no soil cover. However, such an analysis may be more complex to adapt to an automatic detection on digital elevation model. Gas can escape, where gravel and stones are outcropping, but related depressions are missing as they require soft material, soil, or very recent sediments as with gas venting in marine environment.

Fairy Circles
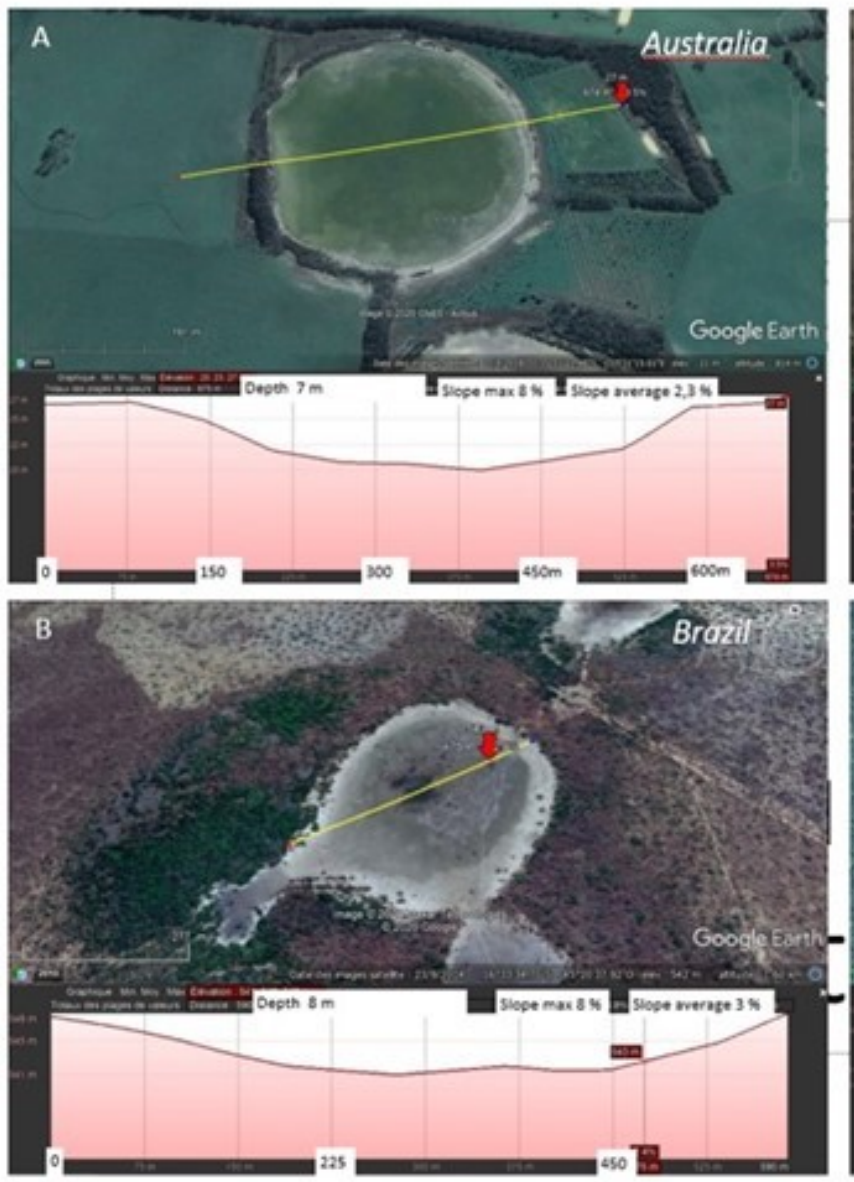

Figure 7. Examples of depressions. Left fairy circles, respectively in Australia (A) and Brazil (B). Right karstic dolines. The one in Spain $(\mathbf{C})$ is dry and so the exact depth could be measured. At the opposite extreme is the Yucatan karstic system (D) where the bottom of the sinkholes is an active cave passage which is always filled of water. The depth measured by satellite images is therefore a minimum. Note the shape is similar but that the depth and especially the slopes are different between the two kinds of structures. 


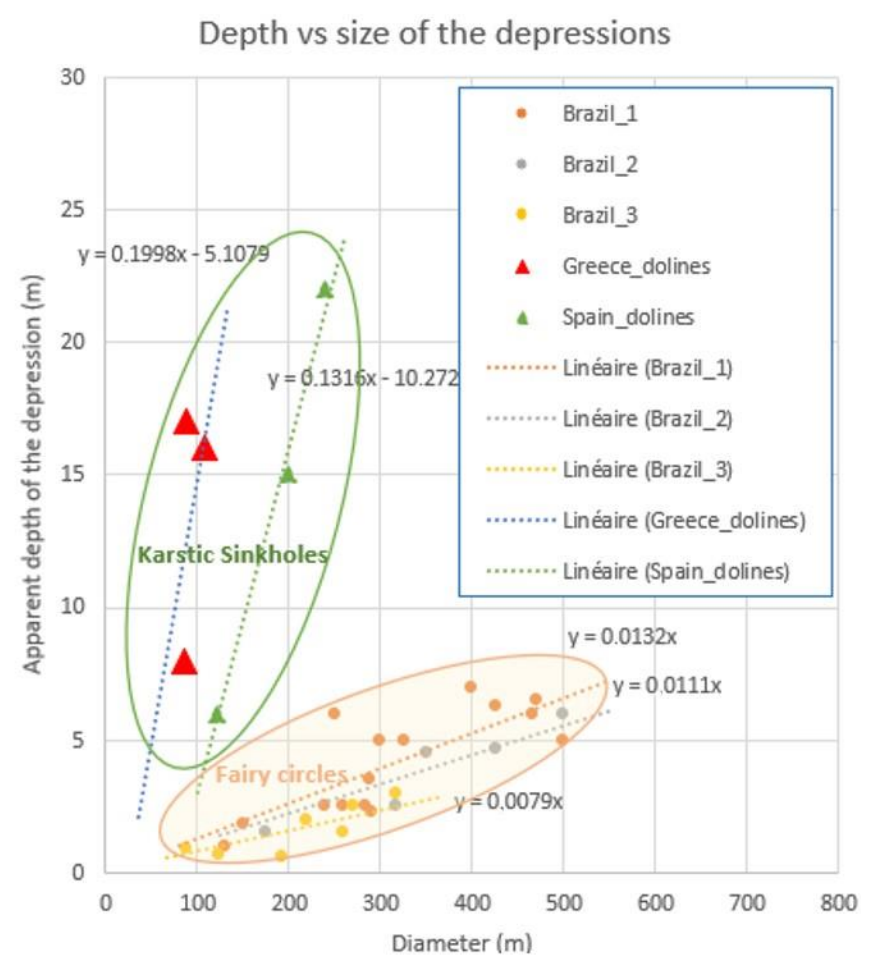

Figure 8. Relationship between size and depth for the studied fairy circles and for dolines from Greece and Spain. The relation size/depth is not perfect for the fairy circles but remains around $1 \%$. This relation is different for the dolines, which range to deeper depressions.

\section{Data Set on $\mathrm{H}_{2}$ Prospective Zone}

\subsection{Mapped Structures near Perth}

The basement of southwest part of Australia is mainly composted of an Archean Craton, the Yilgarn Craton. There are very numerous zones above or at the border of the Craton where depressed structures are visible. In addition, the presence of numerous Iron ore mines suggests a potential source of hydrogen. We mapped three of these zones, (1) the "Serpentine" area, Serpentine is a small town about $30 \mathrm{~km}$ south, southeast of Perth, (2) the Pingrup area at about $300 \mathrm{~km} \mathrm{SE}$ of Perth, and (3) the Esperance area. North of the city of Esperance a very large area is full of structures. We do not have enough well data to prove that they are related to $\mathrm{H}_{2}$ escape but we will discuss here why, taking into account the geology and the structural characteristics of these structures, we consider that it is worth studying them.

Along the western coast, the basement under the Perth Basin and the Carnarvon Basin corresponds to the Mesoproterozoic Pinjarra Orogen [41] which is covered by about $14 \mathrm{~km}$ of sediments. A major N-S fault separates the Proterozoic from the deep Mesozoic basin.

For the Serpentine area, the mapping in presented Figure 9A. The average and the size distribution (Table 3) are similar to the ones near Adelaide; however, we did not observe any very small or very large structure in this zone. The density is variable, globally about $4 \%$ of the land is covered by fairy circles but locally this ratio may surpass $50 \%$. 

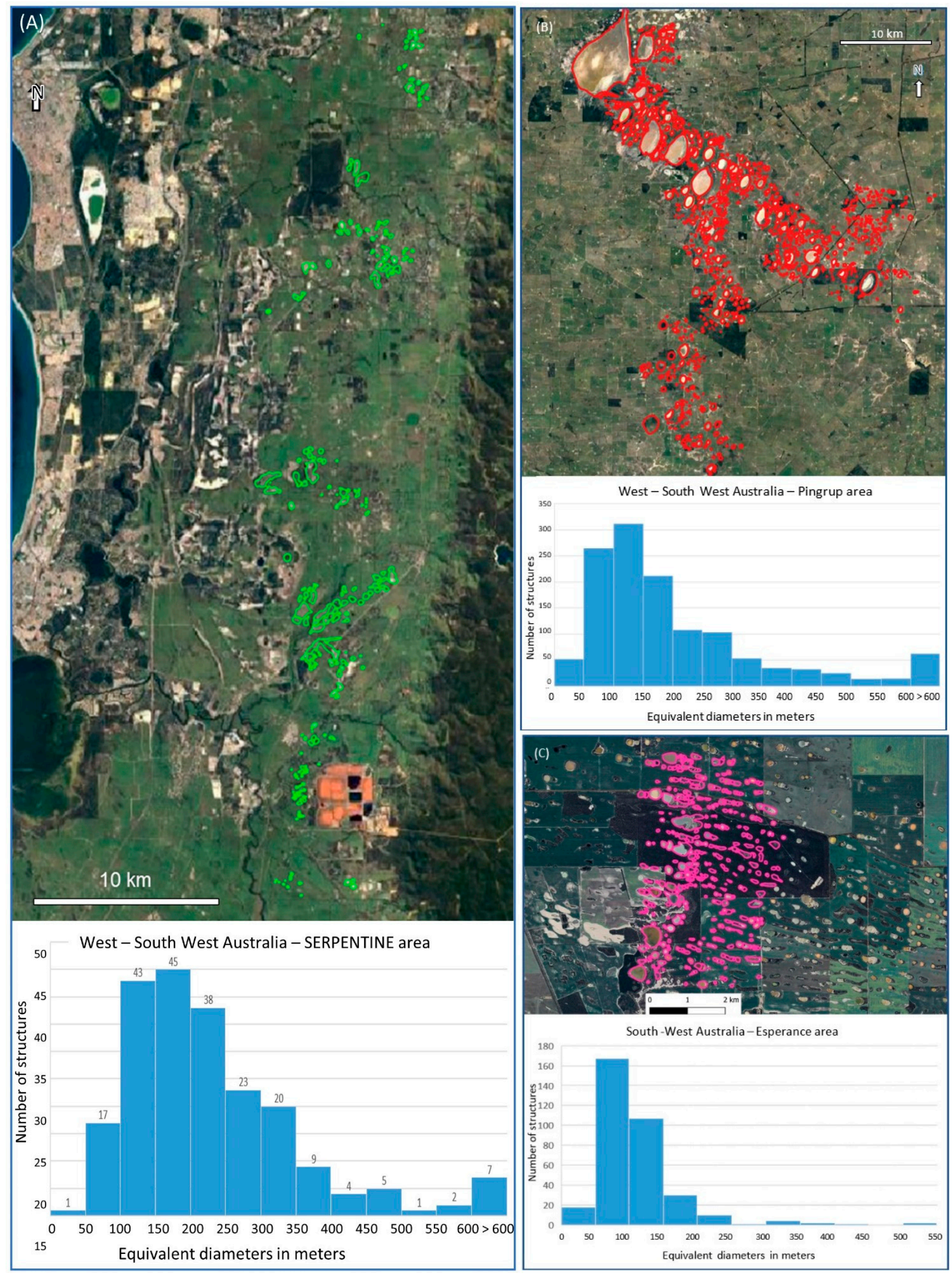

Figure 9. The mapping and the diameter equivalent statistic for fairy circles in the Perth Area, South-West Australia. (A) serpentine area, (B) Pingrup area, (C) Esperance area. 
Table 3. Comparison of the characteristics between the 5 mapped areas in Australia.

\begin{tabular}{|c|c|c|c|c|c|}
\hline & \multicolumn{2}{|c|}{ Adelaide Area-Gawler Craton } & \multicolumn{3}{|c|}{ Perth Area-Yilgarm Craton } \\
\hline & Kangaroo Island & $\begin{array}{c}\text { Yorke } \\
\text { Peninsula }\end{array}$ & $\begin{array}{l}\text { Serpentine } \\
\text { Area }\end{array}$ & $\begin{array}{l}\text { Pingrup } \\
\text { Area }\end{array}$ & $\begin{array}{c}\text { Esperance } \\
\text { Area }\end{array}$ \\
\hline $\mathrm{Nb}$ of mapped structures & 121 & 365 & 214 & 1291 & 341 \\
\hline Density (foot print) & $\begin{array}{c}0.93 \% \text { full island } \\
>10 \% \text { near the well }\end{array}$ & $4 \%$ & $4 \%$ & $17 \%$ & \\
\hline Average equiv radius (m) & 218 & 135 & 118 & 113 & 55 \\
\hline Min equiv radius (m) & 10 & 5 & 29 & 9 & 13 \\
\hline Max equiv. Radius (m) & 2102 & 1867 & 536 & 3487 & 270 \\
\hline Ratio depth/diameter & 0.0063 & 0.0064 & 0.0043 & 0.0076 & NNN \\
\hline
\end{tabular}

The Pingrup area is located in the southwestern part of the Yilgarn Craton. The thickness of the sediment is about $200 \mathrm{~m}$, much thinner than in the Perth area and the basement is Archean [52,53]. Data from this zone are presented Figure 9B, and the statistics Table 2. Sizes and distributions are rather similar to the ones observed in other areas with an average radius of $113 \mathrm{~m}$ but the pattern is quite different. The structures mark a river and follow its bed for more than $200 \mathrm{~km}$. It is different from what we observed in Brazil where the structures are located on the top of the hills between the rivers. However, one may note that in this part of Australia the climate is dry and the rivers beds are mainly without water. The sizes are very diverse from 9 to $3487 \mathrm{~m}$ (equivalent diameters), and as in the others places in Australia and Brazil, the structures merge but do not intersect. Salty layers are present and the relative role of the salt dissolution versus the gas escape interpretation proposed here on the shape of the observed structures remains to be better defined. Interpretation of these ellipsoid lakes, which are very often acid, as caused by salt dissolution, or salt displacement, is an alternative interpretation as discussed by [46]. The ratio depth/equivalent diameter is lower than $1 \%$ as in the other places, when using only the circles with a diameter below $1.2 \mathrm{~km}$ the ratio is $0.76 \%$. As in Russia, this relationship disappears for large structures, it is coherent with the fact that the large ones appear as the merge of smallest ones and not as an initially small one that has grown.

\subsection{Mapped Structures near Esperance}

The third zone is south-eastward from Perth, northward on the city of Esperance, the number of structures is much higher and the satellite images are very impressive (Figure 9C). The region looks like a real painting because the small lakes, undoubtedly because of the bacterial activity, all have different color shades. The area is full of small depressions aligned in an east-west direction. Rosary of few in linear structures are common, the biggest one is often westward. The shape suggests a westward migration but trying to map such a migration through the paleo-images available in Google-Earth does not allow us to confirm it. Usually this $\mathrm{E}-\mathrm{W}$ direction is interpreted as due to the wind (CSIRO, E Frery personal communication) and, from our knowledge, until now the hypothesis of depression due to gas escape has yet to be tested. We mapped 341 structures, the pattern being very regular we consider that it is representative of the area. The global maps, mapped areas and distributions are presented in Figure 9C, the values and their means in Table 3. The depth to size ratio has not been computed since the structures are too often full of water.

\section{Discussion}

To summarize, we presented the data from three areas in Brazil and one in Russia where the structures observed are known to be the place of $\mathrm{H}_{2}$ leakage. In Australia, we studied six areas. On three of them, we do not have data on the $\mathrm{H}_{2}$ concentration in the soil but the existence of $\mathrm{H}_{2}$ in subsurface is confirmed in wells drilled on (Kangaroo Island, Yorke Peninsula, and in the Amadeus Basin). In the South West, three other areas have been mapped. 
Again, direct measurement of the $\mathrm{H}_{2}$ emanations are not available on these structures around Perth but similitudes with places where $\mathrm{H}_{2}$ has been proven are reviewed.

\subsection{Size and Density}

To compare the structures from the various areas we presented their size distribution. Figure 10 highlights the homogeneity (or the heterogeneity) of this distribution and Figure 11 shows the histograms. They are smoothed and normalized by the number of structures for given range size intervals with the maximum number of structures of the calculated histogram. This corresponds to a normalization with the number of points corresponding to the maximum probability of size, for a given area. Figure 10 compares the dispersion of the sizes. In Brazil, average and more probable values are roughly the same. In Brazil zone 1 and zone 2 almost all the fairy circles have similar sizes. On the third Brazilian (blue) zone, the number of small structures is larger. It is also observed on the histogram Figure $4 \mathrm{~A}$ but this kind of figure allows comparing different zones on Earth that may have very different data density (i.e., of measured structures). In Figure 11, the $\mathrm{X}$-axes for the diameters are presented in logarithmic scales, in order to visualize a possible log-normal distribution. For the majority of structure sets, the statistical repartition is close to log-normal (zones 1 and 2 from Brazil, Russia, Serpentine, Esperance, and Pingrup in Australia), with a maximum varying between 90 and $200 \mathrm{~m}$ in diameters (Figure 11 bottom). The other areas (zone 3 of Brazil, Kangaroo Island, and Yorke Peninsula in Australia) present a bimodal repartition, with the main Gaussian-type in log-scale (maximum probability of diameters between 150 and $300 \mathrm{~m}$ for the different areas respectively), and smaller peaks with smaller diameters (around 20-25 $\mathrm{m}$ in diameter).

Since many structures grow by coalescence, it is tempting to consider the bimodal distributions represent an early stage of structure growth with a disproportionate number of smaller structures still present. 

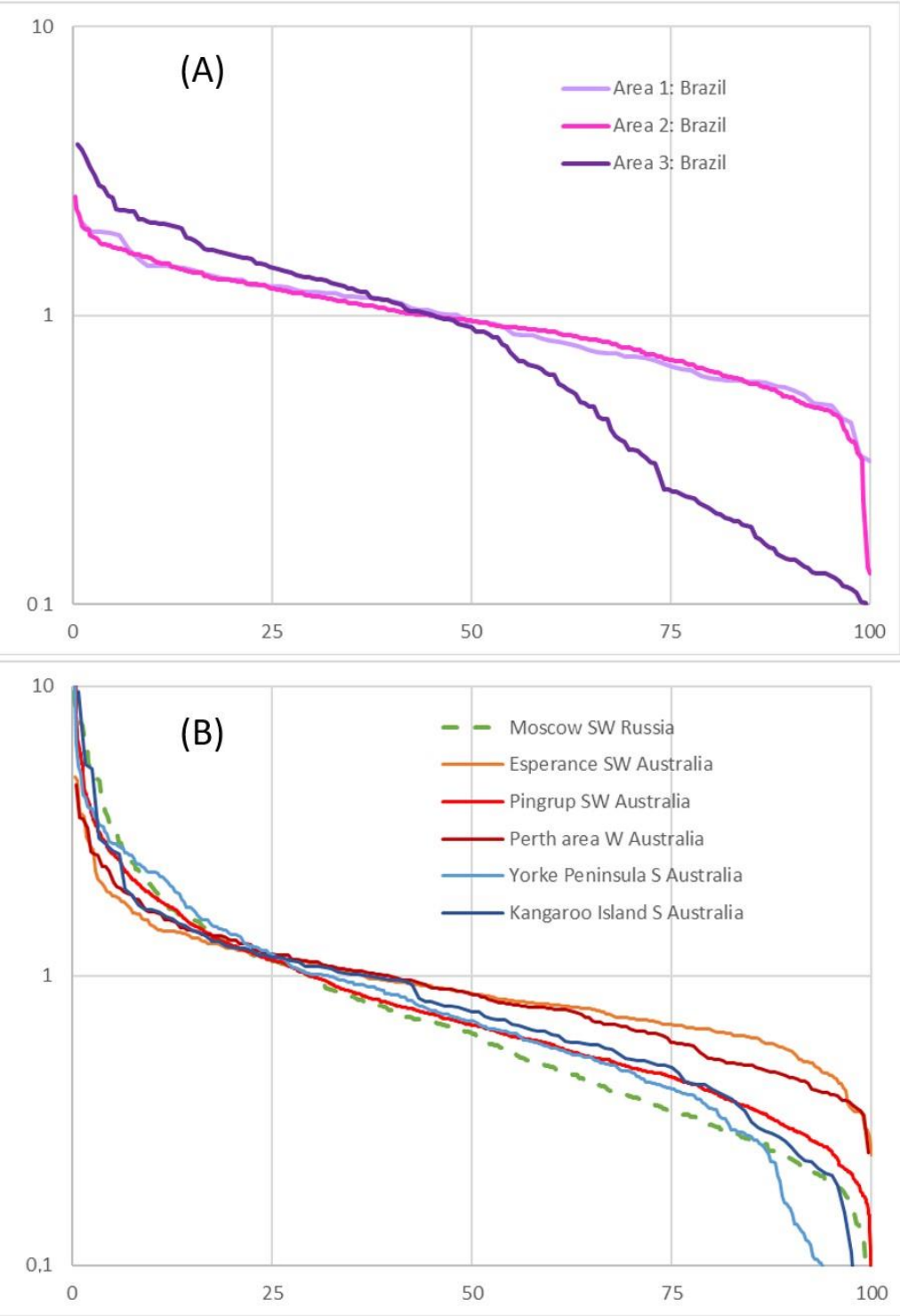

Figure 10. Distribution of the diameters in normalized values on the average. (A): data set from Brazil. (B): data set from Russia and Australia. Logarithmic scale on the vertical axis. This figure shows the dispersion of the values. A curve almost horizontal and where the value 1 is reached at $50 \%$ means that almost all the structures have the same dimension and that the average value and the most probable value are almost the same. 


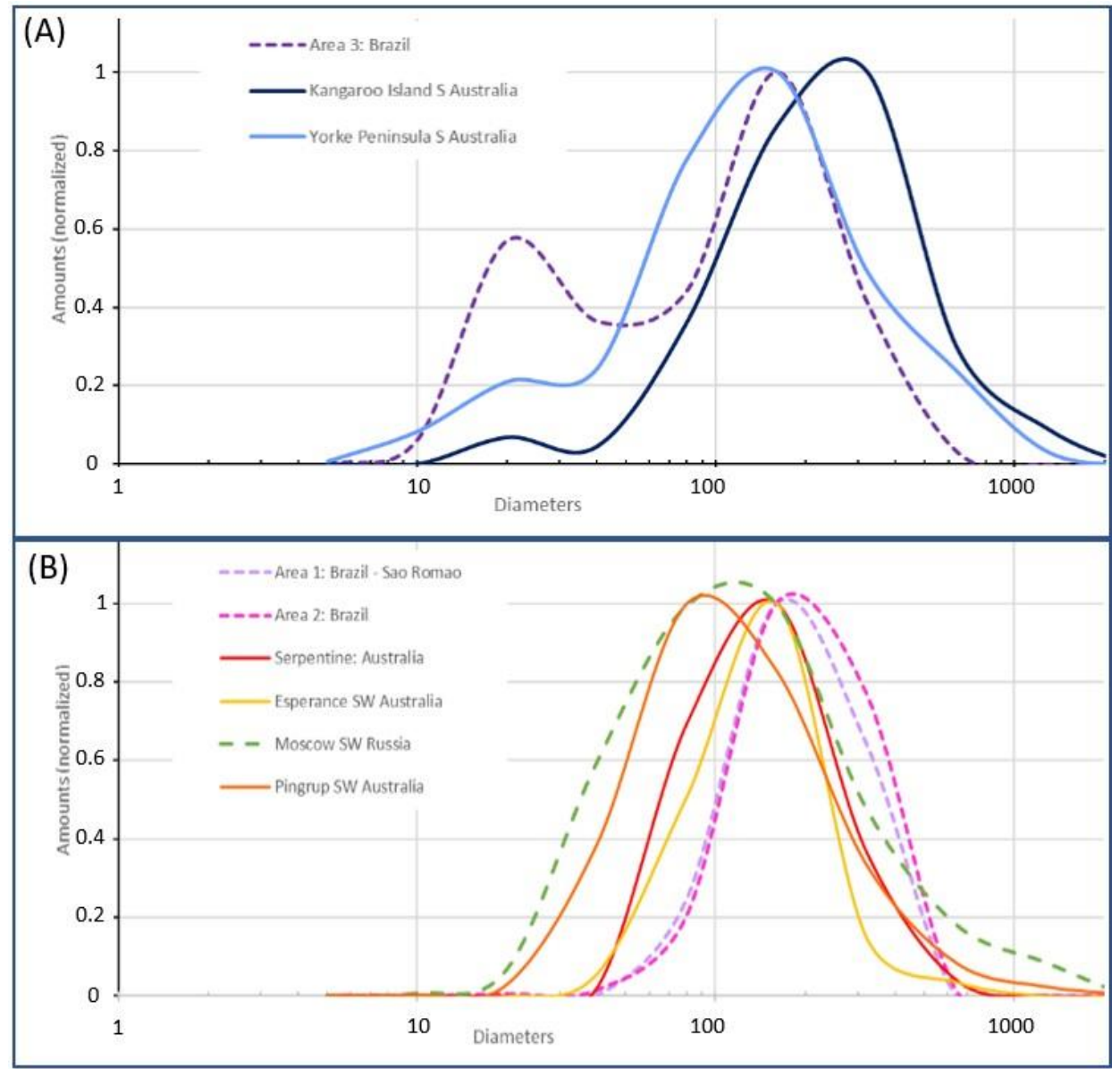

Figure 11. Normalized distribution of the diameters deduced from the raw data Figures 4,8 and 9. (A) The ones which present two maxima, zone 3 in Brazil, and the Adelaide area. (B) The ones with a simple maximum: Russia and the other areas in Brazil and Australia. The more probable values are between $150 \mathrm{~m}$ and $200 \mathrm{~m}$ except for Kangaroo Island where it is larger.

\subsection{Shape and Structural Location}

In order to compare the size of the mapped structures we discussed the results until now in terms of equivalent radius. However, the images clearly show that these structures are not perfectly circular, but often have a convex rather irregular shape. In the Carolina Bay in the USA, perfect ellipses corresponding the $\mathrm{H}_{2}$ emitting structures have been described [22]. The lidar (light laser detection and ranging) images of these structures, called bays, are spectacular and have often been published, e.g., [54]. In that case, the principal axis direction of the ellipses is quite constant N130/140 and the shape ratio (major axis/minor axis) ranges between 1.6 and 1.8. The structures are rather large and often filled with water. The Jones Lake Bay which has been the most studied is $2400 \times 1500 \mathrm{~m}$ large but it is not the largest one. As in Russia and Brazil, the structures are located in the relief between the river beds (see Figure 1 on [22]) but there are various differences with the cases presented in that paper. The structures may intersect without merging and some small structures are located inside the large ones (see Figure 2 on [22]).

In all the cases studied here, Brazil and Australia, the structures mainly grow by coalescence. The elongated shape when it exists, seems due to the merge of initially rather circular small ones in a line in a given direction. In Russia, the spatial repartition has been interpreted as due to the presence of leaking faults [8] but geomorphological reasons may also be the cause. In Brazil, the emitting structures are always on the hills between the rivers parallel to these morpho-structural features. We did not observe fairy circles in the bed of the rivers. The presence of clay in the river bed could be a causality since permeability strongly influences the $\mathrm{H}_{2}$ migration pathway as modeled by [55] or even 
the intermittent presence of water. In this part of Brazil, the dry and rainy seasons are very contrasted. During the rainy season the water table is much higher and could erase newly formed depression.

The relief of the $\mathrm{H}_{2}$ emitting structures is also different in South Carolina, the bays are often marked by a ring of positive relief, a kind of sand dune that borders the ellipses. There is no or almost no depression within the structures but because they overlap and intersect, it is difficult to define a baseline to quantify their depths. Up to now it is the only place where we observed these characteristics. In Brazil we only noted depressions with no positive reliefs around.

\subsection{Absence of Visible Leakage}

In the O\&G industry, lack of surface oil and gas seeps does not means that there is no $\mathrm{HC}$ accumulations in a basin. It is apparently the same for hydrogen accumulation. In the Amadeus Basin, $\mathrm{H}_{2}$ was found in wells below the regional salt seal and there are no fairy circles in the central part of the basin, so potentially no apparent seal leakage in the center of the basin. This characteristic may be due to the presence of the Gillen Evaporites, a thick layer within the basin. However, this behavior of an evidenced hydrogen system observed through drilling, and the scarcity of fairy circles, is also visible in Mali, in the Bourakebougou area where there is no salt but another effective seal, a dolerite [4]. In addition, these two areas are covered with a deep layer of laterites and locally with ferruginous crust. These laterites are related to tropical weathering and are enriched in goethite and hematite, mainly in the most altered and superficial part of the alteration profile, the so-called ferruginous crust. The experimental work of Alpermann and coworkers $[56,57]$ indicates that hematite has the ability to oxidize $\mathrm{H}_{2}$ without any biological help and in subsurface conditions. The experiments were conducted at high pressure (100 bars) and low temperatures (70 to $120{ }^{\circ} \mathrm{C}$ ), and no evidence of a pressure effect is available so far. However, it is also possible that biology adds a useful catalyst allowing a very rapid destruction of $\mathrm{H}_{2}$ when the soil is hematite-rich, which is the case for laterites. This may explain why in lateritic environments, where $\mathrm{H}_{2}$ systems have been evidenced (New Caledonia [58]; Mali [4]), there is a scarcity of fairy circles. It may be also the case in the Amadeus basin.

Thus, even if the presence of fairy circles is a positive signal, their absence cannot be interpreted in term of $\mathrm{H}_{2}$ potential.

\subsection{Exploration Strategy from Space Image}

The statistical approach developed here allows us to propose various criteria for an automatic detection by remote sensing of the gas emitting structures and to differentiate them from other depressed circular areas such as dolines.

1. The slope: fairy circles related to know $\mathrm{H}_{2}$ leakage always present gentle slopes of a few $\%$. At the opposite the dolines have very steep borders with a slope usually above $50 \%$.

2. The fairy circles are never very deep, less than $10 \mathrm{~m}$ in our current database which contains about 2000 samples. The presence of water may result in an underestimation of this threshold.

3. The existence of a relationship between the depth and the size of the small structures (equiv diameter $<1 \mathrm{~km}$ ). The depth/diameter ratio is usually around $1 \%$, often even smaller and never over 3\%. For the karst depressions, the bases of dolines correspond usually to the bottom of the carbonated bed which has been dissolved and so the depth is not dependent on the size.

4. As additional criteria to eliminate carbonate dissolution structures is the absence of soil. A void, a negative topography structure through consolidated outcropping rock cannot be related to gas escape. In this context, gas and more generally fluids migrate through faults and fractures, they do not spread out creating large structures.

The size distributions of the fairy circles in Russia, Brazil, and around Adelaide, the areas where $\mathrm{H}_{2}$ has been proven, are very similar and seem to us representative of the gas 
escape context. The average radius is around $250 \mathrm{~m} \mathrm{(+/}-50 \mathrm{~m})$, around $20 \mathrm{~m}$ for the smallest ones and the very large ones (more than $1 \mathrm{~km}$ of radius) are rare.

The proposed slope-based criteria, maximum and average, seems more relevant than just the maximum depth, size, and circularity proposed to recognize karst depressions in the São Francisco Basin by [59]. These works were not dedicated to differentiate dolines from gas escape depression but dolines from everything else. We suspect, based on our analysis, that a couple of the depressions classified as "dolines" are related to gas escape and not to karst dissolution since they are too gentle depressions. Moreover, some structures that they do not consider, for good reasons, as dolines may be natural (their classification is "natural" vs. man-made) and related to $\mathrm{H}_{2}$ leakage since the geology of this area is close to the studied ones (i.e., Brazil 1, 2 and 3).

\section{Conclusions and Implications}

Use of natural resources such as the iron and the bitumen always started historically by taking advantage of the surface indices. The first open-pit mines came latter and were just a few meters long or deep. Some of them are still visible and are part of the prehistorical archaeological heritage. In a second step, the early explorationists started drilling or mining near the surface indices and only in a next phase, the geological knowledge of the system allowed drilling on concepts, in area devoid of surface indices.

Long before the oil industry dedicated to energy sourcing as we know it, the ancients civilizations used oil seeps to create mommies 4000 years BC, or bitumen to waterproof wooden boats and broken recipients. Six thousand years later, the O\&G industry started and only a few decades later, generally their geoscientists have been able to convince their management to drill blind structures without any oil or gas seep around. We are at a similar decision point today, but we do not know yet how long it will take to a predictive understanding of the $\mathrm{H}_{2}$ system (generation/migration/accumulation). However, we quickly need to have new parameters to derisk the first phase of exploration wells dedicated to natural hydrogen. In intracratonic basins, production possibilities are proven in Mali, active $\mathrm{H}_{2}$ generation in Brazil and accumulation in Kansas (USA). What can we hope for in Australia?

\subsection{Australian Natural $\mathrm{H}_{2}$ Potential}

In the areas of Kangaroo Island and Yorke Peninsula, there is no doubt that $\mathrm{H}_{2}$ is generated and that migration pathways exist from the kitchen of generation to the surface. The total area occupied by the fairy circle is large (41 and $47 \mathrm{~km}^{2}$, respectively) hydrogen flow seeping out is probably very large, maybe more than $100 \mathrm{t} /$ days if the flow is similar to the ones measured in the fairy circles in Brazil $\left(3 \mathrm{t} /\right.$ day $\left./ \mathrm{km}^{2}\right)$. The high density of fairy circles may be interpreted has a lack of seal but $\mathrm{H}_{2}$ rich gas was found at depth in the two tested wells. Therefore, it seems reasonable to look for a trap and to drill it. The quality of the reservoir, in terms of porosity and permeability, will be key for an economic production. In both wells, the tested reservoirs were Precambrian limestones.

In the Amadeus Basin, the subsurface is rather similar but in addition there is a regional seal, the Bitter Springs evaporite sequence, Cryogenian in age, enabling retention of $\mathrm{H}_{2}$ large accumulations. Salt is a proven seal for $\mathrm{H}_{2}$ and almost all the subsurface $\mathrm{H}_{2}$ storage facilities are in salt cavities [60]. The presence of these seals and of many traps due to the compressive phases make this basin very promising for $\mathrm{H}_{2}$ exploration in terms of reserves.

For the $\mathrm{H}_{2}$ economy, the transport of $\mathrm{H}_{2}$ being non-trivial, the distance to the costumer is a key factor. For the natural gas, onshore as offshore, the construction of a pipeline may be a critical economic decision point. In fact, many small gas discoveries have never been put into production. They are sometimes taken over later by small companies that produce electricity directly on site for a local market. We can anticipate the same kind of challenges for small $\mathrm{H}_{2}$ fields, proximity to the consumer will be a key element for the natural hydrogen economy, except in cases where a large daily production will justify 
the construction of a pipeline. As for the natural gas, and as what happens today in Mali, the local production of electricity will remain an option. Comparing Amadeus Basin versus near Adelaide locations, a small production may result more economically realistic in the second case.

For the areas around Perth, the data are more fragmented and it is difficult to give today a probability of success for a natural $\mathrm{H}_{2}$ exploration in that zone. However, the similarities, that we highlighted in the presented work, with the areas where a $\mathrm{H}_{2}$ system is working are obvious and not fortuitous. The morphology of the surface indicators is the same as in Mali, Brazil, Russia, and Adelaide and iron rich levels in subsurface are good candidate as hydrogen source rock. It would therefore seem judicious to us to take over the existing data with this in mind and to acquire new ones as also proposed by [46]. Surface data acquisition campaigns with a GA5000 type detector to confirm, or deny, the presence of hydrogen in all these structures would be a first step. The monitoring of some of the active ones follows.

\section{2. $\mathrm{H}_{2}$ Onshore Potential above Archean and Proterozoic Crusts}

The few trials of $\mathrm{H}_{2}$ exploration potential highlighted the serpentinization as the more promising process to generated $\mathrm{H}_{2}$. Reference [5] computed that the Semail Ophiolite in Oman may have generated $109 \times 10^{12}$ trillion cubic feet of $\mathrm{H}_{2}$ during its serpentinization. It means about $277 \mathrm{MT}$, i.e., about four years of the current world $\mathrm{H}_{2}$ consumption. This ophiolitic sheet is large $500 \mathrm{~km} \times 50 \mathrm{~km}$ and $5 \mathrm{~km}$ thick, it is the largest known one, but at the Earth scale, it is just one point.

On a large scale, Proterozoic cratons represent a quite substantial proportion of the Earth continental surface. From our experience on natural hydrogen exploration in cratons, it appears that the Neoproterozoic formations are the most commonly presenting fairy circles and hydrogen seeps. This geological period has been extensively studied, as it appears that the Earth atmosphere at that time (limit Cryogenian-Ediacaran, i.e., 635 M.y.) loses the major part of its $\mathrm{O}_{2}$, due to severe cooling of the Earth [61]. This cooling implies that the major part of the Earth is covered with ice, reducing the role of photosynthesis and oxygen emissions. The Earth is then in a very reducing conditions, allowing new episode of BIF formation (Banded Iron Formations) as described in [62]. It was already happening between 2.5 and 1.8 billion years ago, when the ferrous iron dissolved in the ocean oxidized and precipitated, because of the beginning of the photosynthesis process oxidizing first the oceans before releasing oxygen into the atmosphere [63].

The occurrence of natural hydrogen within these Neoproterozoic formations, interpreted both in Brazil [64,65] and in Australia [66] as periods of large Earth temperature variations and important episodic loss of $\mathrm{O}_{2}$ in the atmosphere, may be related to the reduced form of mineral paragenesis. Even if more studies would be needed to confirm the correlation between hydrogen systems and Neoproterozoic rocks, because of the reduced form of the rocks, or because of the presence of iron precipitation in larger amounts, allowing $\mathrm{H}_{2}$ generation through its further oxidation.

The other places where this Neoproterozoic and associated BIF are mentioned are Namibia [67], Egypt [68], China, USA, and Canada [62] whereas the Archean to Paleoproterozoic BIF are also mentioned in South Africa and Zimbabwe, amongst others. In addition of the fairy circles presence, it could be another parameter to check when starting exploring for $\mathrm{H}_{2}$ reserves.

\subsection{Hydrogen System vs. Petroleum System}

The petroleum system concepts as well as all the tools that allow us to quantify the fluid circulation within the subsurface have been shaped after years of researches and data acquisition. For the hydrogen system, as presented in introduction, the system, i.e., the set of parameters that must be met for a deposit to exist, will have similarities but also differences. Source, migration pathway, reservoirs, and seals remain mandatory. The various sources of $\mathrm{H}_{2}$ are becoming better known and the rate of the generation 
appears to be fast. If, as it is subscript in Mali, and as it is clearly the case in all the smokers and volcanic areas, $\mathrm{H}_{2}$ is continuously generated by the water/rock interaction it will be present in the gas, or dissolved gas as long as water is available. The size of the reservoirs is not an issue, as one may consider a replenishment of the reservoir through human times as for geothermal reservoirs. This represents a main difference with the petroleum systems. From our point of view, the migration pathways; hence the potential distance between the source rock and the accumulation, remain the least well-known part of the system.

Author Contributions: All authors contributed to the data interpretation and to the writing of this paper which has been finalized by I.M. A.P. did the $\mathrm{H}_{2}$ measurements on the soils in Brazil. E.B. worked on the Australia case, K.L. did the mapping and statistic on the Brazilian fairy Circles under the supervision of I.M. E.D. and A.P. participated to the field acquisition in Russia. All authors have read and agreed to the published version of the manuscript.

Funding: This research has been paid by UPPA. The master shcolarship of E.B. has been paid by ENGIE.

Institutional Review Board Statement: Not applicable.

Informed Consent Statement: Not applicable.

Data Availability Statement: All the data are in the cited literature. Mapping of the structures could be done from open access satellite image.

Acknowledgments: We are extremely grateful to Slava Zgonnik for providing us with the cartographic data for the Russian case. We thank Fadi Nader, IFPen, for the review of our proposal to differentiate on carbonate dissolution structures and fairy circles. We thank also Joao Francolin (Georisk, Rio) for data in Brazil and Olivier Sissmann for many discussions on natural hydrogen. The master scholarship of Emily Brouilly has been paid by ENGIE. We thank the reviewers and specially Chris Boreham for his constructive comments.

Conflicts of Interest: the authors declare no conflict of interest.

\section{References}

1. Prinzhofer, A.; Deville, É. L'hydrogène Naturel ou la Prochaine Révolution Energétique? Collection: Essais; Editions Belin: Paris, France, 2015; 199p, ISBN 978-2-7011-8384-8.

2. Moretti, I. H2: Energy vector or source? Actual. Chim. 2019, 442, 15-16.

3. Gaucher, E.C. New Perspectives in the Industrial Exploration for Native Hydrogen. Elements 2020, 16, 8-9. [CrossRef]

4. Prinzhofer, A.; Cissé, C.S.T.; Diallo, A.B. Discovery of a large accumulation of natural hydrogen in Bourakebougou (Mali). Int. J. Hydrogen Energy 2018, 43, 19315-19326. [CrossRef]

5. Smith, N.J.P.; Shepherd, T.J.; Styles, M.T.; Williams, G.M. Hydrogen exploration: A review of global hydrogen accu-mulations and implications for prospective areas in NW Europe. In Petrology Geology: North-West Europe and Global Perspec-tives-Proceedings of the 6th Petroleum Geology Conference; Doré, A.G., Vining, B.A., Eds.; Petroleum Geology Conference Series 6; Geological Society: London, UK, 2005; pp. 349-358.

6. Sato, M.; Sutton, A.J.; McGee, K.A.; Russell-Robinson, S. Monitoring of hydrogen along the San Andreas and Calaveras faults in central California in 1980-1984. J. Geophys. Res. Space Phys. 1986, 91, 12315-12326. [CrossRef]

7. Etiope, G.; Lollar, B.S. Abiotic Methane on Earth. Rev. Geophys. 2013, 51, 276-299. [CrossRef]

8. Larin, N.; Zgonnik, V.; Rodina, S.; Deville, E.; Prinzhofer, A.; Larin, V.N. Natural Molecular Hydrogen Seepage Associated with Surficial, Rounded Depressions on the European Craton in Russia. Nat. Resour. Res. 2014, 24, 369-383. [CrossRef]

9. Truche, L.; McCollom, T.M.; Martinez, I. Hydrogen and Abiotic Hydrocarbons: Molecules that Change the World. Elements 2020, 16, 13-18. [CrossRef]

10. Charlou, J.L.; Fouquet, Y.; Bougault, H.; Donval, J.P.; Etoubleau, J.; Jean-Baptiste, P.; Dapoigny, A.; Appriou, P.; Rona, P.A. Intense $\mathrm{CH} 4$ plumes generated by serpentinization of ultramafic rocks at the intersection of the $15^{\circ} 20^{\prime} \mathrm{N}$ fracture zone and the Mid-Atlantic Ridge. Geochim. Cosmochim. Acta 1998, 62, 2323-2333. [CrossRef]

11. McCollom, T.M.; Klein, F.; Robbins, M.; Moskowitz, B.; Berquó, T.S.; Jöns, N.; Bach, W.; Templeton, A. Temperature trends for reaction rates, hydrogen generation, and partitioning of iron during experimental serpentinization of olivine. Geochim. Cosmochim. Acta 2016, 181, 175-200. [CrossRef]

12. Worman, S.L.; Pratson, L.F.; Karson, J.A.; Schlesinger, W.H. Abiotic hydrogen (H2) sources and sinks near the Mid-Ocean Ridge (MOR) with implications for the subseafloor biosphere. Proc. Natl. Acad. Sci. USA 2020, 117, 13283-13293. [CrossRef]

13. Vacquand, C.; Deville, E.; Beaumont, V.; Guyot, F.; Sissmann, O.; Pillot, D.; Arcilla, C.; Prinzhofer, A. Reduced gas seepages in ophiolitic complexes: Evidences for multiple origins of the H2-CH4-N2 gas mixtures. Geochim. Cosmochim. Acta 2018, 223, 437-461. [CrossRef] 
14. Okland, I.; Huang, S.; Thorseth, I.H.; Pedersen, R.B. Formation of H2, CH4 and N-species during low-temperature experimental alteration of ultramafic rocks. Chem. Geol. 2014, 387, 22-34. [CrossRef]

15. Bachaud, P.; Meiller, C.; Brosse, E.; Durand, I.; Beaumont, V. Modeling of Hydrogen Genesis in Ophiolite Massif. Procedia Earth Planet. Sci. 2017, 17, 265-268. [CrossRef]

16. Kularatne, K.; Sissmann, O.; Kohler, E.; Chardin, M.; Noirez, S.; Martinez, I. Simultaneous ex-situ CO 2 mineral sequestration and hydrogen production from olivine-bearing mine tailings. Appl. Geochem. 2018, 95, 195-205. [CrossRef]

17. Brunet, F. Hydrothermal Production of H2 and Magnetite From Steel Slags: A Geo-Inspired Approach Based on Olivine Serpentinization. Front. Earth Sci. 2019, 7. [CrossRef]

18. Murray, J.; Clément, A.; Fritz, B.; Schmittbuhl, J.; Bordmann, V.; Fleury, J.M. Abiotic hydrogen generation form biotite-rich granite: A case study of the Soultz-sous-forets geothermal site, France. Appl. Geochem. 2020, 119, 104631. [CrossRef]

19. Lollar, B.S.; Onstott, T.C.; Lacrampecouloume, G.; Ballentine, C.J. The contribution of the Precambrian continental lithosphere to global H2 production. Nature 2014, 516, 379-382. [CrossRef]

20. Larin, V.N. Hydridic Earth the New Geology of Our Primordially Hydrogen-Rich Planet; Warren, H.C., Ed.; Polar Pub: Calgary, AB, Canada, 1993; 247p.

21. Zgonnik, V. The occurrence and geoscience of natural hydrogen: A comprehensive review. Earth Sci. Rev. 2020, 203, 103140. [CrossRef]

22. Zgonnik, V.; Beaumont, V.; Deville, E.; Larin, N.; Pillot, D.; Farrell, K.M. Evidence for natural molecular hydrogen seepage associated with Carolina bays (surficial, ovoid depressions on the Atlantic Coastal Plain, Province of the USA). Prog. Earth Planet. Sci. 2015, 2, 31. [CrossRef]

23. Prinzhofer, A.; Moretti, I.; Françolin, J.; Pacheco, C.; D’Agostino, A.; Werly, J.; Rupin, F. Natural hydrogen continuous emission from sedimentary basins: The example of a Brazilian H2-emitting structure. Int. J. Hydrogen Energy 2019, 44, 5676-5685. [CrossRef]

24. Moretti, I.; Prinzhofer, A.; Françolin, J.; Pacheco, C.; Rosanne, M.; Rupin, F.; Mertens, J. Long-term monitoring of natural hydrogen superficial emissions in a brazilian cratonic environment. Sporadic large pulses versus daily periodic emissions. Int. J. Hydrogen Energy 2021, 46, 3615-3628. [CrossRef]

25. Tschinkel, W.R. The Life Cycle and Life Span of Namibian Fairy Circles. PLoS ONE 2012, 7, e38056. [CrossRef] [PubMed]

26. Tschinkel, W.R. Experiments Testing the Causes of Namibian Fairy Circles. PLoS ONE 2015, 10, 1-22. [CrossRef]

27. Myagkiy, A.; Brunet, F.; Popov, C.; Krüger, R.; Guimarães, H.; Sousa, R.S.; Charlet, L.; Moretti, I. H2 dynamics in the soil of a H2-emitting zone (São Francisco Basin, Brazil): Microbial uptake quantification and reactive transport modelling. Appl. Geochem. 2020, 112, 104474. [CrossRef]

28. Charlou, J.; Donval, J.; Fouquet, Y.; Jean-Baptiste, P.; Holm, N. Geochemistry of high H2 and CH4 vent fluids issuing from ultramafic rocks at the Rainbow hydrothermal field (36 $\left.14^{\prime} \mathrm{N}, \mathrm{MAR}\right)$. Chem. Geol. 2002, 191, 345-359. [CrossRef]

29. Bazarkina, E.F.; Chou, I.-M.; Goncharov, A.F.; Akinfiev, N.N. The Behavior of H2 in Aqueous Fluids under High Temperature and Pressure. Elements 2020, 16, 33-38. [CrossRef]

30. Veikkolainen, T.; Pesonen, L.J.; Evans, D.A.D. PALEOMAGIA: A PHP/MYSQL database of the Precambrian paleomagnetic data. Stud. Geophys. Geod. 2014, 58, 425-441. [CrossRef]

31. Maia, A.R.; Cartwright, J.; Andersen, E. Shallow plumbing systems inferred from spatial analysis of pockmark arrays. Mar. Pet. Geol. 2016, 77, 865-881. [CrossRef]

32. Gay, A.; Lopez, M.; Cochonat, P.; Levaché, D.; Sermondadaz, G.; Séranne, M. Evidences of early to late fluid migration from an upper Miocene turbiditic channel revealed by 3D seismic coupled to geochemical sampling within seafloor pockmarks, Lower Congo Basin. Mar. Pet. Geol. 2006, 23, 387-399. [CrossRef]

33. Boyd, D.; Anka, Z.; di Primio, R.; Kuhlmann, G.; de Wit, M.J. Passive margin evolution and controls on natural gas leakage in the Orange Basin, South Africa. S. Afr. J. Geol. 2011, 114, 349-366. [CrossRef]

34. Moss, J.; Cartwright, J. The spatial and temporal distribution of pipe formation, offshore Namibia. Mar. Pet. Geol. 2010, 27, 1216-1234. [CrossRef]

35. Cartwright, J.; Santamarina, C. Seismic characteristics of fluid escape pipes in sedimentary basins: Implications for pipe genesis. Mar. Pet. Geol. 2015, 65, 126-140. [CrossRef]

36. Cathles, L.; Prinzhofer, A. What Pulsating H2 Emissions Suggest about the H2 Resource in the Sao Francisco Basin of Brazil. Geosciiences 2020, 10, 149. [CrossRef]

37. Truche, L.; Joubert, G.; Dargent, M.; Martz, P.; Cathelineau, M.; Rigaudier, T.; Quirt, D. Clay minerals trap hydrogen in the Earth's crust: Evidence from the Cigar Lake uranium deposit, Athabasca. Earth Planet. Sci. Lett. 2018, 493, 186-197. [CrossRef]

38. Reis, H.L.S.; Alkmim, F.F.; Fonseca, R.C.S.; Nascimento, T.C.; Suss, J.F.; Prevatti, L.D. The São Francisco Basin. In São Francisco Craton, Eastern Brazil: Tectonic Genealogy of a Miniature Continent; Springer: Berlin/Heidelberg, Germany, 2016 ; pp. 117-143.

39. Donzé, F.-V.; Truche, L.; Namin, P.S.; Lefeuvre, N.; Bazarkina, E.F. Migration of Natural Hydrogen from Deep-Seated Sources in the São Francisco Basin, Brazil. Geosciences 2020, 10, 346. [CrossRef]

40. Iaccheri, L.M. Composite basement along the southern margin of the North Australian Craton: Evidence from in-situ zircon $\mathrm{U}-\mathrm{Pb}-\mathrm{O}-\mathrm{Hf}$ and whole-rock $\mathrm{Nd}$ isotopic compositions. Lithos 2019, 324, 733-746. [CrossRef]

41. Markwitz, V.; Kirkland, C.L.; Evans, N.J. Early Cambrian metamorphic zircon in the northern Pinjarra Orogen: Implications for the structure of the West Australian Craton margin. Lithosphere 2016, 9, 3-13. [CrossRef]

42. Olierook, H.K.; Agangi, A.; Plavsa, D.; Reddy, S.M.; Yao, W.; Clark, C.; Occhipinti, S.A.; Kylander-Clark, A.R. Neoproterozoic hydrothermal activity in the West Australian Craton related to Rodinia assembly or breakup? Gondwana Res. 2019, 68, 1-12. [CrossRef] 
43. Morrissey, L.J.; Barovich, K.M.; Hand, M.; Howard, K.E.; Payne, J.L. Magmatism and metamorphism at ca. 1.45 Ga in the northern Gawler Craton: The Australian record of rifting within Nuna (Columbia). Geosci. Front. 2019, 10, 175-194. [CrossRef]

44. Hill, R.L. Lithogeochemical Characterisation of Cover Sequence on Yorke Peninsula, South Australia, and Identification of Pathfinder Elements for IOCG Exploration. Master's Thesis, University of Adelaide, Adelaide, Australia, $2015 ;$ p. 67.

45. Weinberg, R.F.; Hasalová, P.; Ward, L.; Fanning, C.M. Interaction between deformation and magma extraction in migmatites: Examples from Kangaroo Island, South Australia. Geol. Soc. Am. Bull. 2013, 125, 1282-1300. [CrossRef]

46. Rezaee, R. Natural Hydrogen System in Western Australia? 2020, 2020100589, Preprints. [CrossRef]

47. Ward, L.K. Inflammable gases occluded in the pre-palaeozoic rocks of south Australia. Trans. R. Soc. S. Aust. 1933, 57, 42-47.

48. Johns, D.; Menpes, A.; Walshe, P.; Bache, F. Exploration of a Sub-Salt Play in the Southern Amadeus Basin, Central Austra-lia-Searching for Big Gas in Proterozoic Réservoirs; Seapex Presentation; Seapex: Singapore, 2017.

49. Boreham, C.J.; Sohn, J.H.; Cox, N.; Williams, J.; Hong, Z.; Kendrick, M.A. Hydrogen and hydrocarbons associated with the Neoarchean Frog's Leg Gold Camp, Yilgarn Craton, Western Australia. Chem. Geol. 2021, 120098. [CrossRef]

50. Ford, D.C.; Williams, P.W. Karst Hydrogeology and Geomorphology; John Wiley \& Sons Ltd.: Chichester, UK, $2007 ;$ p. 562.

51. Palmer, A.N. Cave Geology; Cave Research Foundation: Kansas City, KS, USA, 2007; p. 454.

52. Salama, W.; Anand, R.R.; Verrall, M. Mineral exploration and basement mapping in areas of deep transported cover using indicator heavy minerals and paleoredox fronts, Yilgarn Craton, Western Australia. Ore Geol. Rev. 2016, 72, 485-509. [CrossRef]

53. Anand, R.; Hough, R.; Salama, W.; Aspandiar, M.; Butt, C.; González-Álvarez, I.; Metelka, V. Gold and pathfinder elements in ferricrete gold deposits of the Yilgarn Craton of Western Australia: A review with new concepts. Ore Geol. Rev. 2019, 104, 294-355. [CrossRef]

54. Prinzhofer, A.; Deville, E. De L'hydrogène Naturel Sous nos Pieds; Pour la Science: Paris, France, 2015 ; Volume 456.

55. Myagkiy, A.; Moretti, I.; Brunet, F. Space and time distribution of subsurface H2 concentration in so-colled «fairy-circles »: Insight from a conceptual 2-D transport model. BSGF Earth Sci. Bull. 2020, 191, 13. [CrossRef]

56. Alpermann, T.; Ostertag-Henning, C. Dry Abiotic Oxidation of H2 by Hematite, Pyrite, and Other Redox-Active Minerals at Subsurface Conditions (120 ${ }^{\circ} \mathrm{C} 200$ Bar). In Proceedings of the Goldschmidt Conference, Barcelona, Spain, 18-23 August 2019.

57. Alpermann, T.; Ostertag-Henning, C. Kinetics of the Abiotic Oxidation of Hydrogen (H2) by Hematite at Subsurface Storage Conditions. In Proceedings of the Goldschmidt Conference, Virtual. 21-26 June 2020.

58. Deville, E.; Prinzhofer, A. The origin of N2-H2-CH4-rich natural gas seepages in ophiolitic context: A major and noble gases study of fluid seepages in New Caledonia. Chem. Geol. 2016, 440, 139-147. [CrossRef]

59. De Carvalho, J.O.A.; Guimarães, R.F.; Montgomery, D.R.; Gillespie, A.R.; Gomes, R.A.T.; Martins, É.D.S.; Silva, N.C. Karst Depression Detection Using ASTER, ALOS/PRISM and SRTM-Derived Digital Elevation Models in the Bambuí Group, Brazil. Remote Sens. 2013, 6, 330-351. [CrossRef]

60. Panfilov, M. Underground and pipeline hydrogen storage. Compend. Hydrog. Energy 2016, 2016, 91-115. [CrossRef]

61. Yeung, L.Y. Low oxygen and argon in the Neoproterozoic atmosphere at 815 Ma. Earth Planet. Sci. Lett. 2017, 480, 66-74. [CrossRef]

62. Lei, R.X.; Zhang, K.; Muhtar, M.N.; Wu, C.Z. Neoproterozoic non-glaciogenic iron formation: Insights from Fe isotope and elemental geochemistry of the Shalong iron formation from the Central Tianshan block, southern Altaids. Precambrian Res. 2020, 351, 105959. [CrossRef]

63. Schidlowski, M. Evolution of photoautotrophy and early atmospheric oxygen levels. Precambrian Res. 1983, 20, 319-335. [CrossRef]

64. Santos, R.V.; de Alvarenga, C.J.S.; Dardenne, M.A.; Sial, A.N.; Ferreira, V.P. Carbon and oxygen isotope profiles across MesoNeoproterozoic limestones from central Brazil: Bambu1' and Paranoa' groups. Precambrian Res. 2000, 104, 107-122. [CrossRef]

65. Hiatt, E.E.; Pufahl, P.K.; da Silva, L.G. Iron and phosphorus biochemical systems and the Cryogeni-an-Ediacaran transition, Jacadigo basin, Brazil: Implications for the Neoproterozoic oxygenation event. Precambrian Res. 2020, 337, 105533. [CrossRef]

66. Ward, J.F.; Verdel, C.; Campbell, M.J.; Leonard, N.; Nguyen, A.D. Rare earth element geochemistry of Australian Neopro-terozoic carbonate: Constraints on the Neoproterozoic oxygenation events. Precambrian Res. 2019, 35, 105471. [CrossRef]

67. Bechstädt, T.; Jäger, H.; Rittersbacher, A.; Schweisfurth, B.; Spence, G.; Werner, G.; Boni, M. The Cryogenian Ghaub Formation of Namibia-New insights into Neoproterozoic glaciations. Earth Sci. Rev. 2018, 177, 678-714. [CrossRef]

68. Ali, R.A.; Pitcairn, I.K.; Maurice, A.E.; Azer, M.K.; Bakhit, B.R.; Shahien, M.G. Petrology and geochemistry of ophiolitic ul-tramafic rocks and chromitites across the Eastern Desert of Egypt: Insights into the composition and nature of a Neoprote-rozoic mantle and implication for the evolution of SSZ system. Precambrian Res. 2020, 337, 105565. [CrossRef] 